\title{
Nucleobase and Nucleoside Analogues: Resistance and Re-Sensitisation at the Level of Pharmacokinetics, Pharmacodynamics and Metabolism
}

\author{
Nikolaos Tsesmetzis ${ }^{1}$, Cynthia B. J. Paulin ${ }^{2}$, Sean G. Rudd ${ }^{2, * \text { (ID }}$ and Nikolas Herold ${ }^{1,3, * \text { (ID) }}$ \\ 1 Childhood Cancer Research Unit, Department of Women's and Children's Health, Karolinska Institutet, \\ 17177 Stockholm, Sweden; nikolaos.tsesmetzis@ki.se \\ 2 Science for Life Laboratory, Department of Oncology-Pathology, Karolinska Institutet, \\ 17165 Stockholm, Sweden; cynthia.paulin@scilifelab.se \\ 3 Paediatric Oncology, Theme of Children's and Women's Health, Karolinska University Hospital Solna, \\ 17176 Stockholm, Sweden \\ * Correspondence: sean.rudd@scilifelab.se (S.G.R.): nikolas.herold@ki.se (N.H.)
}

Received: 1 July 2018; Accepted: 20 July 2018; Published: 23 July 2018

\begin{abstract}
Antimetabolites, in particular nucleobase and nucleoside analogues, are cytotoxic drugs that, starting from the small field of paediatric oncology, in combination with other chemotherapeutics, have revolutionised clinical oncology and transformed cancer into a curable disease. However, even though combination chemotherapy, together with radiation, surgery and immunotherapy, can nowadays cure almost all types of cancer, we still fail to achieve this for a substantial proportion of patients. The understanding of differences in metabolism, pharmacokinetics, pharmacodynamics, and tumour biology between patients that can be cured and patients that cannot, builds the scientific basis for rational therapy improvements. Here, we summarise current knowledge of how tumour-specific and patient-specific factors can dictate resistance to nucleobase/nucleoside analogues, and which strategies of re-sensitisation exist. We revisit well-established hurdles to treatment efficacy, like the blood-brain barrier and reduced deoxycytidine kinase activity, but will also discuss the role of novel resistance factors, such as SAMHD1. A comprehensive appreciation of the complex mechanisms that underpin the failure of chemotherapy will hopefully inform future strategies of personalised medicine.
\end{abstract}

Keywords: chemoresistance; sensitisation; novel therapy; combination therapy; antimetabolites; nucleoside analogues; nucleobase analogues; cytarabine; gemcitabine; clofarabine; fludarabine; nelarabine; cladribine; 5-fluorouracil; capecitabine; SAMHD1; ribonucleotide reductase; precision medicine

\section{Introduction}

Since metastatic potential is a hallmark of cancer [1], management of malignant disease usually requires systemic treatment in order to prevent and treat tumour spread. Combination chemotherapy still constitutes the current paradigm to achieve systemic disease control in clinical oncology, even though immunotherapeutic approaches are becoming a viable complement at least for a subset of patients [2,3]. Antimetabolites were the first class of cytotoxic drugs systematically tested in clinical trials that elicited complete clinical responses as monotherapies, albeit with inevitable relapse [4]. Even though this review will-with few exceptions-mainly focus on monotherapy, it is important to keep in mind that, empirically, combination of chemotherapeutic agents is a sine qua non for the cure of the vast majority of cancers. On the other hand, a reductionist understanding of the mechanisms underlying the insufficiency of monotherapies is a prerequisite to rationally improve existing therapy 
modalities. This review aims to give an overview of the current understanding of chemoresistance, but will exclusively focus on nucleoside and nucleobase analogues (Figure 1), the major subgroup of antimetabolites.

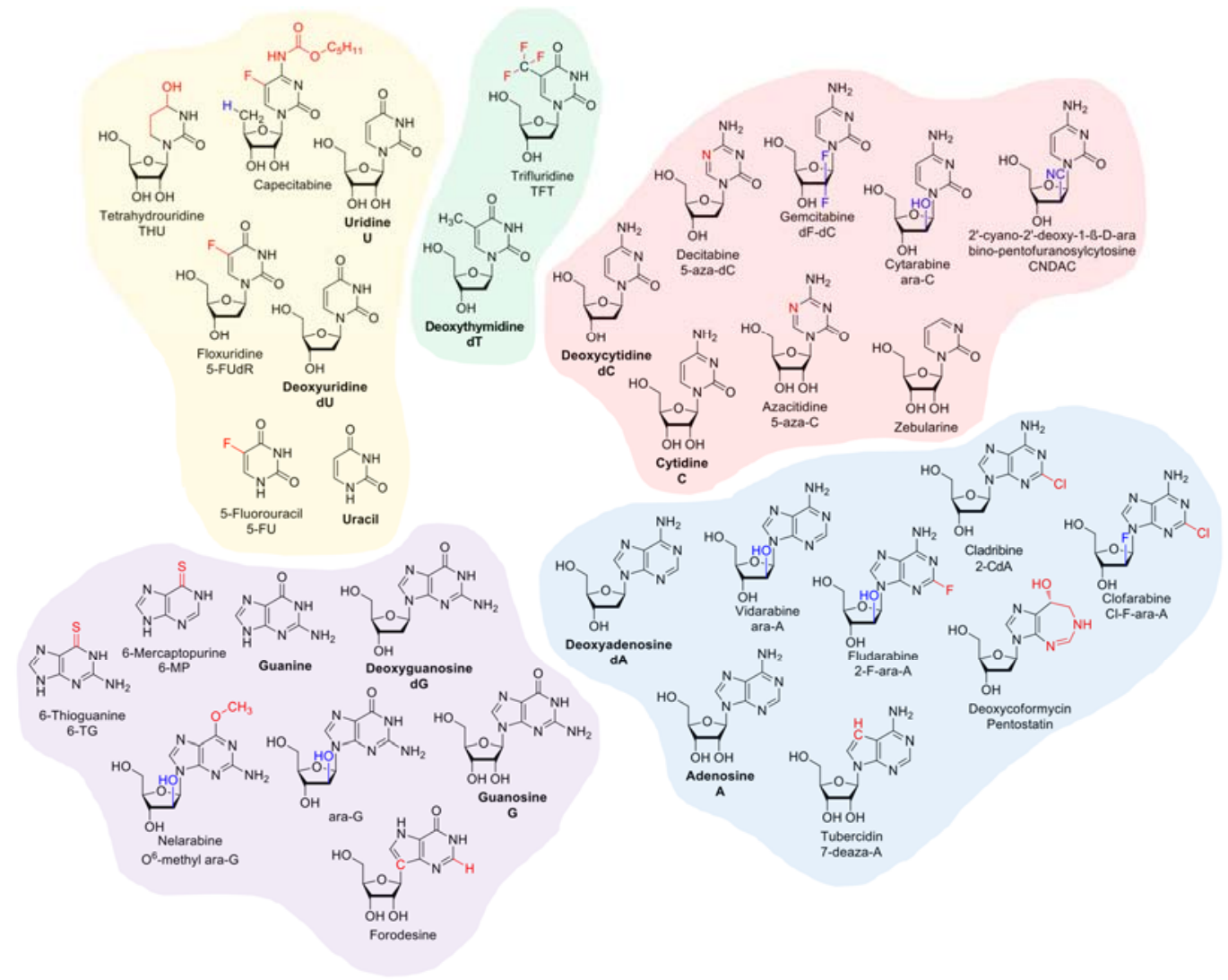

Figure 1. Structures of nucleobase and nucleoside analogues discussed in this review. Endogenous nucleobase/nucleosides are labelled in bold and synthetic analogues with sugar-modifications (indicated in blue) or base-modifications (indicated in red) are shown.

Antimetabolites can be grouped into folate antagonists and nucleobase/nucleoside analogues. Due to their structural similarity, folate antagonists, or antifolates, either inhibit conversion of dihydrofolate to tetrahydrofolate by targeting dihydrofolate reductase (DHFR) or directly inhibit one or more of the enzymes that require tetrahydrofolate as a co-factor, e.g., phosphoribosylglycinamide formyltransferase (GARFT) and thymidylate synthase (TS); key enzymes in de novo synthesis of nucleic acid precursors (discussed in more detail below) [5,6]. Antifolates are, however, not within the scope of the current review article; comprehensive reviews are to be found elsewhere $[7,8]$.

Nucleobase and nucleoside analogues exert their cytotoxic effects by mimicking endogenous nucleosides (and following phosphorylation, nucleotides). This can either be mediated by enzyme inhibition or by substituting endogenous nucleoside species as substrates, leading to DNA and RNA damage and interference with DNA methylation. Nucleoside analogues have to reach tumour sites, niches and sanctuaries at sufficient concentration (delivery) and in a non-degraded form (stability), be taken up into the cancer cell (usually by nucleoside transport proteins), and be converted into their active metabolites (activation) before they can hit their molecular target (pharmacodynamic activity) (Figure 2 and Table 1). Both disease- and patient-specific treatment failure to one or several nucleobase or nucleoside analogues can be caused at one or more of these steps. Strategies to rationally improve antimetabolic treatments have thus to take into account all of these mechanisms and assess their relative contribution. 


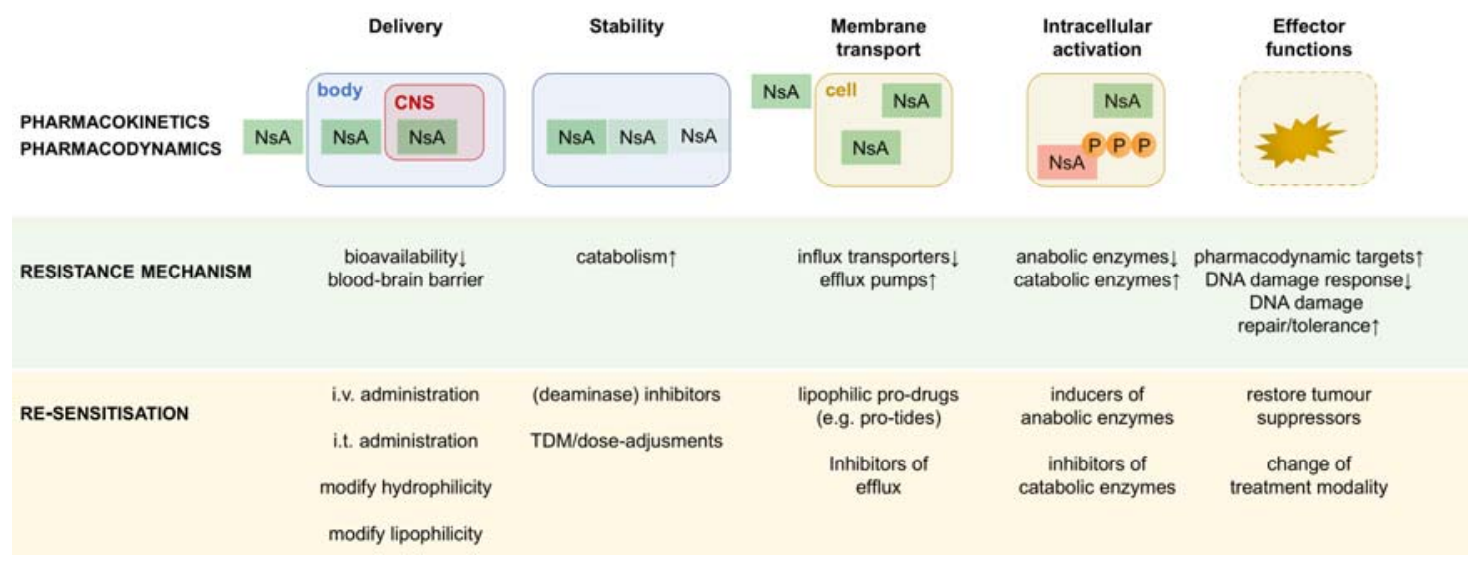

Figure 2. Schematic representation of the levels of resistance to nucleobase/nucleoside analogues. Resistance to nucleobase/nucleoside analogues can occur at the pharmacokinetic levels of delivery (e.g., due to the blood-brain barrier), stability (e.g., due to plasmatic catabolic activity), membrane transport (e.g., due to down-regulation of influx transporters), and intracellular activation (due to an imbalance in anabolic and catabolic enzymes). Further downstream, pharmacodynamic resistance can occur (e.g., due to overexpression of drug targets). Drug efficacy critically depends on the underlying tumour biology that determines the general susceptibility to cytotoxicity (for details, see text). Examples for re-sensitisation strategies are given. NsA, nucleoside analogue; TDM, therapeutic drug monitoring; CNS, central nervous system. 
Table 1. Overview on pharmacokinetic and pharmacodynamic factors for nucleobase/nucleoside analogues, resistance mechanisms, and strategies of re-sensitisation.

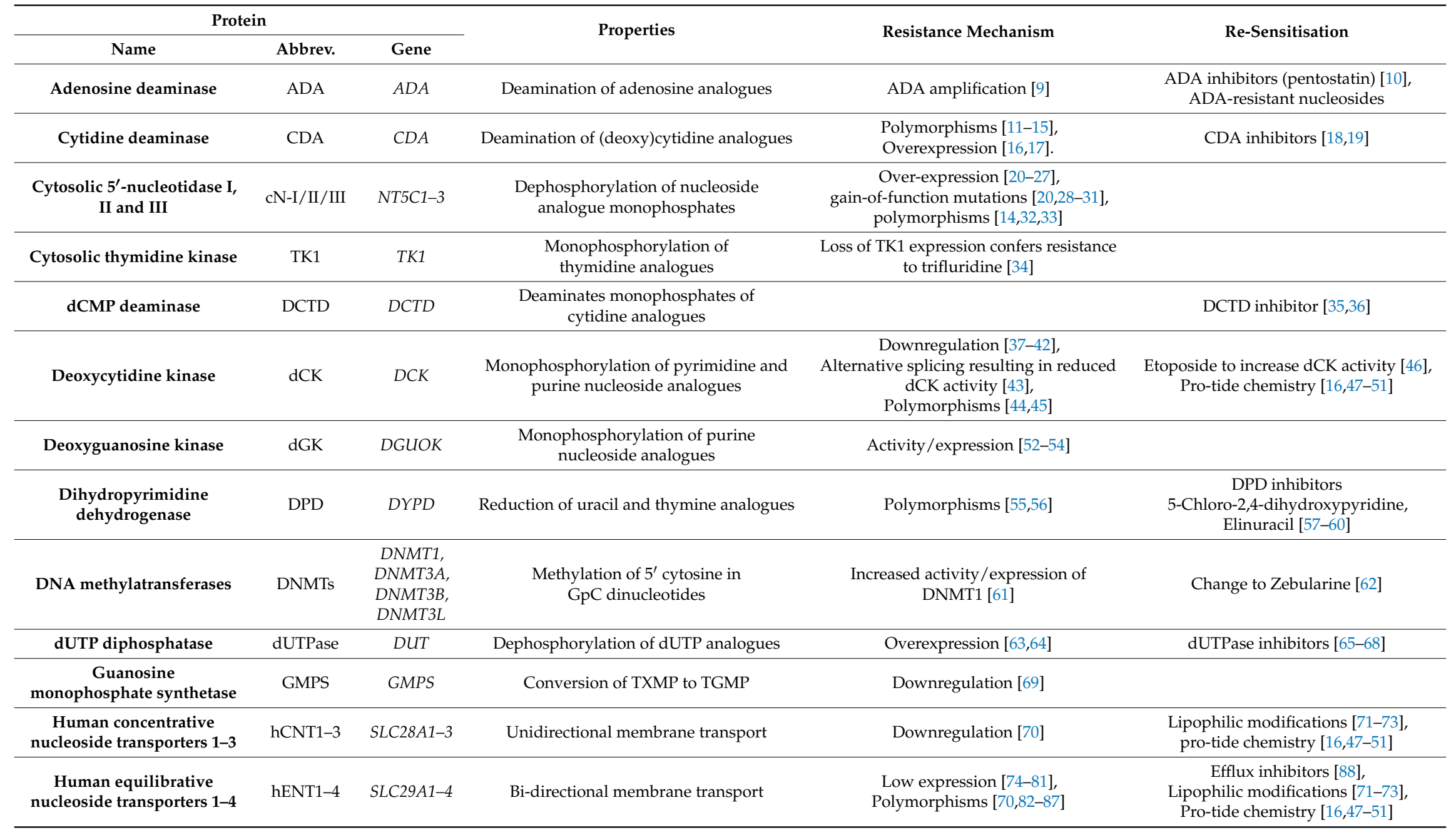


Table 1. Cont

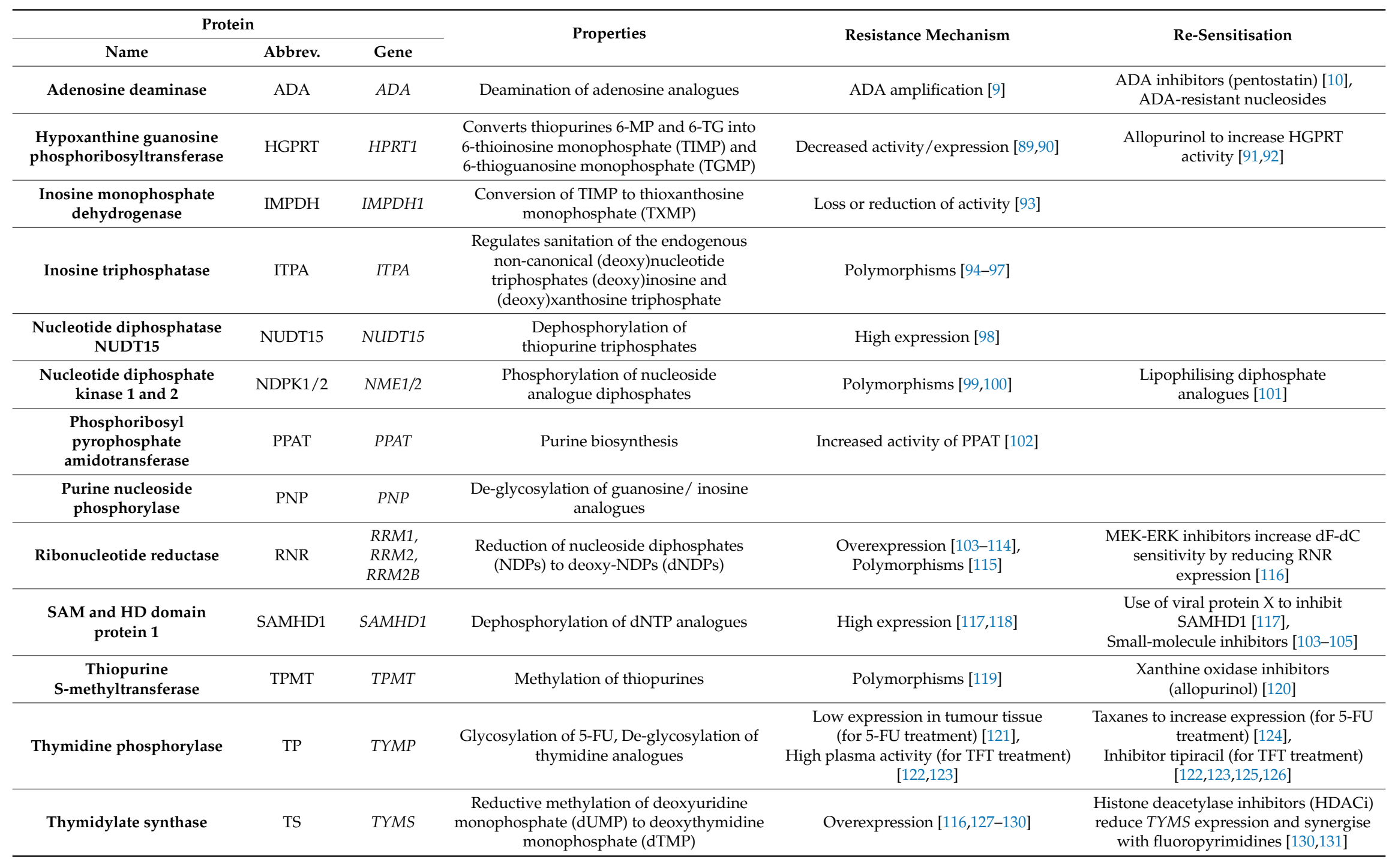


Table 1. Cont.

\begin{tabular}{|c|c|c|c|c|c|}
\hline \multicolumn{3}{|c|}{ Protein } & \multirow{2}{*}{ Properties } & \multirow{2}{*}{ Resistance Mechanism } & \multirow{2}{*}{ Re-Sensitisation } \\
\hline Name & Abbrev. & Gene & & & \\
\hline UMP/CMP kinase & UCK & CMPK1 & $\begin{array}{l}\text { Phosphorylates cytidine and uridine } \\
\text { analogue monophosphates }\end{array}$ & $\begin{array}{l}\text { Downregulation [132], } \\
\text { Polymorphisms }[133,134]\end{array}$ & Lipophilising diphosphate analogues [101] \\
\hline $\begin{array}{l}\text { Uridine monophosphate } \\
\text { synthetase }\end{array}$ & UMPS & UMPS & Conversion of 5-FU to 5-FUMP & Downregulation [135] & \\
\hline Uridine phosphorylase 1 & UP1 & UPP1 & $\begin{array}{c}\text { Glycosylation of 5-FU, } \\
\text { De-glycosylation of 5-FdUrd }\end{array}$ & Expression [136] & $\begin{array}{l}\text { UP1 inhibitors (cell-line dependent effects) } \\
\text { [137] }\end{array}$ \\
\hline
\end{tabular}




\section{Overview on the Pharmacodynamics of Nucleobase and Nucleoside Analogues}

All nucleobase and nucleoside chemotherapeutics are pro-drugs, requiring chemical modification, typically multiple, such as sequential phosphorylation, to generate their active metabolites, even though nucleoside analogues themselves (i.e., no phosphates) can have inhibitory activities towards enzymes in vitro [138]. Because of this, these compounds interact with many cellular targets and perturb as many cellular processes, with an obvious focus upon nucleotide and nucleic acid metabolism. Thus, the mode of action of these compounds is multi-faceted. However, following decades of research, principal mechanisms of action have come into focus for the majority of these compounds (Figure 3), which are discussed below.

One common target of this family of compounds is DNA synthesis, as the triphosphate forms can compete with their endogenous dNTP counterparts for utilisation by DNA polymerases, thus being incorporated into the DNA molecule. For some of these analogues, owing to the replacement of the deoxyribose sugar with arabinose or another modified sugar moiety, these compounds perturb the DNA synthetic reaction, typically the extension step from the mis-incorporated analogue. Although sometimes referred to as chain terminators, these sugar modified analogues should rather be considered as 'relative' chain terminators. Extension from these termini is still possible, and occurs in cells and in vitro, unlike antiviral dideoxynucleosides, which lack the 3 '-OH required for DNA synthesis, and are thus bona fide chain terminators. For instance, the triphosphate metabolite of cytarabine (ara-C) is readily incorporated into DNA by cellular replicases in vitro, with an efficiency comparable with dCTP. However, the extension from the mis-incorporated ara-CMP terminus by these enzymes occurs with a significantly reduced efficiency [139-142]. In line with this, ara-C treated cells quickly accumulate genomic ara-CMP, and this coincides with decreased DNA synthesis and activation of the intra-S-phase checkpoint $[117,143]$, indicating that it is likely this delayed extension, slowing nascent chain synthesis, and the resulting replication fork stalling, that contributes to cancer cell death. This model is supported by a recent study that also highlights the critical role of polymerase proofreading in this process [142]. Although the extension step is perturbed, it still occurs, as evidenced by cells treated with tritiated ara-C incorporating the labelled analogue into growing DNA fragments [144-147]. Other sugar-modified analogues, such as the triphosphate of fludarabine (2-F-ara-ATP), function as stronger chain terminators, evidenced by cells incubated with tritiated fludarabine accumulating this analogue at DNA termini [148]. Cellular effects upon DNA synthesis are likely relative to the abundance of triphosphates present. For instance, in cells incubated with low concentrations of tritiated clofarabine (Cl-F-ara-A), this analogue can be detected at inter-nucleotide linkages. This is consistent with extension from the mis-match and continued DNA synthesis occurring, whilst with high concentrations, this analogue is primarily detected at DNA termini [149], consistent with chain termination. In contrast to these drugs, gemcitabine (dF-dC) triphosphate (dF-dCTP) possesses a unique chain termination activity, in which primer elongation is inhibited following addition of one nucleotide after the mis-incorporated dF-dCMP [150]. This has been termed "masked chain termination" as it would make the mis-incorporated analogue refractory to nuclease-mediated excision [151]. In addition to these mechanisms, the DNA incorporation of the monophosphate of $2^{\prime}$-cyano-2'-deoxy-1- $\beta$-D-arabinopentofuranosylcytosine (CNDAC), CNDACMP, leads to chain termination due to a process called beta-elimination owing to the high electrophilicity of the cyano group at the $2^{\prime}$-carbon [152], resulting in a single-strand DNA break, possibly triggering cell-cycle arrest in the G2-phase [153]. 


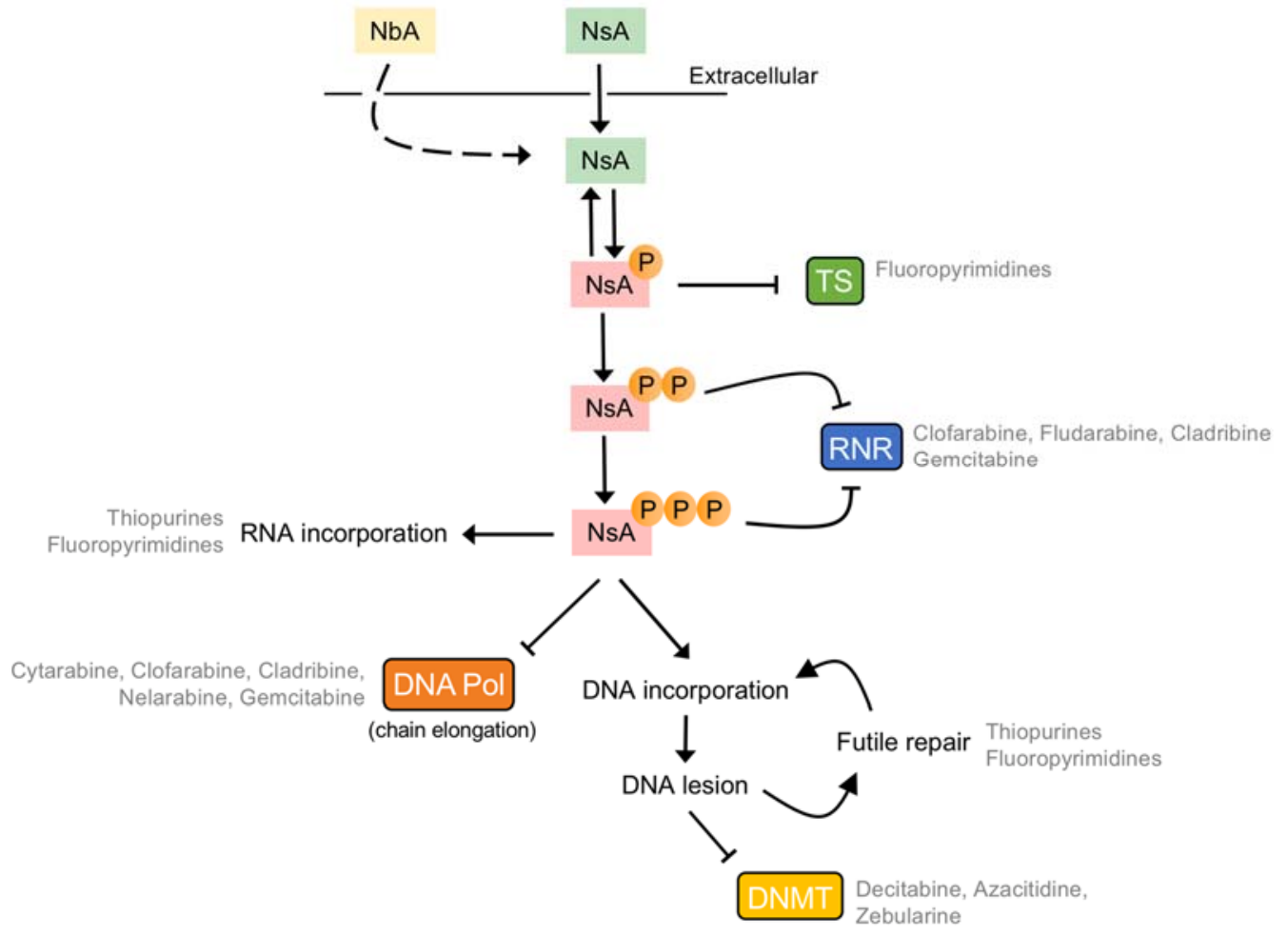

Figure 3. Overview on the pharmacodynamics of nucleobase/nucleoside analogues. Nucleobase ( $\mathrm{NbA}$, light yellow) and nucleoside analogues (NsA, light green) are metabolised intracellularly to produce their active metabolites (NsA, light red), be it the mono- (P), di- (PP) and triphosphate (PPP) species. These can inhibit key enzymes in DNA precursor metabolism, such as thymidylate synthase (TS) or ribonucleotide reductase (RNR), or be incorporated into nucleic acids. Here, these analogues can perturb DNA synthesis by DNA polymerases (DNA Pol) at the extension step, or the resultant genomic lesions can inhibit other enzymes, such as DNA methyltransferases (DNMTs), or lead to futile DNA repair cycles.

Whilst the analogues discussed above have an immediate effect on replicating cells, owing to their modified sugar moieties perturbing DNA synthesis, others, such as decitabine and thiopurines, which lack sugar modification, have a comparatively delayed mechanism of action. The triphosphate metabolite of thiopurines, 6-thio-dGTP, is readily incorporated into the genome, reported to replace canonical guanine nucleotides by up to $0.1 \%$ [154-157], and this incorporation itself is neither toxic nor mutagenic $[155,158,159]$. However, toxicity is triggered when genomic 6-thio-dGMP is non-enzymatically methylated by S-adenosylmethionine (SAM), as following a round of DNA replication, this will result in a 6-MeThio-dG:dT mis-pair [160,161]. In this scenario, the mis-incorporated dT opposite the thioguanine lesion is now recognised as an error by mismatch repair (MMR), a DNA repair pathway that ensures faithful genome duplication, and is subsequently excised from the nascent DNA strand [161], but as the correct pairing cannot be made, this leads to futile repair cycles [162-164]. The resulting unrepaired gaps will then be converted into cytotoxic DNA breaks upon encountering a replication fork in the next S-phase [158,163,165]. It's interesting to note, that, whilst thiopurine cytotoxicity is MMR-dependent, the proficiency of this repair pathway can vary widely amongst T-cell acute lymphoblastic leukaemia (T-ALL) patients [166,167], all of which receive thiopurines during maintenance therapy. Whilst other mechanisms of action exist, including incorporation into RNA of the thiopurine ribonucleotide triphosphate metabolite (6-thio-GTP), perturbing mRNA transcription [168], and inhibition of Rac1 GTPase [169], perhaps the clinical combination of thiopurines with nucleotide biosynthesis inhibitors (such as methotrexate), further promotes 6-thio-dGTP mis-incorporation, overcoming the necessity of MMR. Like thiopurine 
triphosphates, decitabine triphosphate (5-aza-dCTP) can also be readily incorporated into DNA [170], and it is the resultant genomic 5-aza-dCMP that is responsible for this analogues therapeutic effect. When incorporated prior to $\mathrm{dG}$, resulting in a 5-aza-dC-p-dG dinucleotide, this can be recognised by DNA methyltransferases (DNMTs), which typically methylate the 5-position of cytosines present in $\mathrm{CpG}$ dinucleotides to silence gene expression. However, resulting from the chemistry of the methyltransferase reaction with 5-aza-dC, DNMT becomes covalently linked to DNA, generating a DNA-protein cross-link [171-173]. This can lead to two possible outcomes, which may be dependent upon the amount of genomic 5-aza-dCMP. Lower levels of genomic 5-aza-dCMP will lead to tolerable levels of DNMT-DNA crosslinks, which deplete soluble DNMT pools, resulting in global reduction of genomic methylation levels and augmentation of gene expression patterns [174]. However, high genomic 5-aza-dCMP will result in high amounts of DNMT-DNA crosslinks which present a physical block to the DNA synthesis machinery and will result in frequent replication-dependent cytotoxic DNA breaks $[175,176]$, which likely affects cell fitness more immediately than alterations in gene expression patterns. Another DNMT inhibitor following DNA incorporation of its 2'-deoxy variant is the cytidine analogue and cytidine deaminase inhibitor zebularine [62].

In addition to mis-incorporation into DNA and perturbation of DNA metabolism, inhibition of nucleotide metabolism enzymes can also be a key factor in the cytotoxic mechanism of nucleobase and nucleoside analogues. A key enzyme in de novo dNTP biosynthesis is ribonucleotide reductase (RNR), which reduces nucleoside diphosphates (NDPs) to deoxyNDPs (dNDPs), and several of these analogues efficiently target this enzyme. The diphosphate form of gemcitabine (dF-dCDP) is a substrate analogue of RNR [177], demonstrated to be an irreversible suicide inhibitor, becoming covalently bound to the large subunit RRM1 [178]. In contrast, metabolites of purine nucleoside analogues clofarabine (Cl-F-ara-A), fludarabine (2-F-ara-A) and cladribine (2-CdA), all inhibit RNR, but in a reversible manner. In this case, both the di- and triphosphate forms are responsible for RNR inhibition, interacting with the catalytic and allosteric sites respectively, altering the quaternary structure and promoting formation of persistent RRM1 hexamers [179-181]. The dual activity of these purine analogues, and gemcitabine, as RNR and DNA synthesis inhibitors, leads to a mechanism of self-potentiation, in that these analogues inhibit de novo dNTP synthesis that in-turn reduces the level of competing endogenous dNTPs, thus promoting their mis-incorporation into DNA. The mechanism of action of thiopurines has also been linked to inhibition of nucleotide biosynthesis, in particular inhibition of the key purine biosynthesis enzyme phosphoribosyl pyrophosphate amidotransferase (PPAT) by the metabolite methylthioinosine monophosphate [182]. However, the contribution of this to cytotoxicity remains unclear [158], with long-existing evidence arguing the contrary [183].

Another important DNA metabolism target of nucleobase and nucleoside therapeutics is thymidylate synthase (TS), which is irreversibly inhibited by fluoropyrimidines (e.g., 5-FU, floxuridine, 5-FU pro-drug capecitabine) [184,185]. TS catalyses the reductive methylation of deoxyuridine monophosphate (dUMP) to deoxythymidine monophosphate (dTMP), using the folate 5,10-methylenetetrahydrofolate $\left(\mathrm{CH}_{2} \mathrm{THF}\right)$ as the methyl donor [186]. This provides the sole source of de novo dTMP ultimately required for DNA synthesis and is thus considered one of the few metabolic bottlenecks for the synthesis of DNA [185]. The monophosphate form of fluoropyrimidines, 5-F-dUMP, is a substrate analogue, competing with dUMP, and thus binds to the catalytic site of TS resulting in a stable ternary complex with the enzyme and $\mathrm{CH}_{2} \mathrm{THF}$. This prevents normal substrate binding and thus inhibits the enzyme $[187,188]$, which is the basis for enhanced 5-FU efficacy by addition of folinic acid [189]. In addition to 5-FU and derivatives, trifluridine (TFT), activated to TFT monophosphate by thymidine kinases (TKs), also inhibits TS [190]. TS inhibition depletes intracellular dTMP, which in turn leads to a shortage of dTTP (and due to various feedback mechanisms, also perturbs levels of other dNTPs), required for DNA synthesis [191-193]. In addition, dUMP pools become expanded, due to lack of TS activity turning over this metabolite, which can be phosphorylated to dUTP and mis-incorporated into DNA, along with the triphosphate form of fluoropyrimidines (5-F-dUTP and TFT triphosphate, TFT-TP) [194,195]. As 5-F-dUTP, TFT-TP and dUTP are readily 
incorporated into DNA, comparable to dTTP [195-197], a mechanism of self-potentiation is also evident here. Unlike the sugar modified analogues, and much like the thiopurines and decitabine, the use of fluoropyrimidines (or uracil) in DNA synthesis is not cytotoxic itself, however the resultant genomic (fluoro)uracils and trifluorothymines can promote mutagenesis and cytotoxic DNA lesions $[195,198,199]$. Accordingly, DNA repair pathways exist to remove these lesions from the genome, including MMR and base excision repair (BER) [200,201], the latter containing enzymes specifically evolved for the removal of genomic uracil and thymine mis-pairs, such as UNG, SMUG, TDG, and MDB4 [202,203]. However, the abasic site intermediate of BER can be more detrimental to the cell than the original DNA lesion, especially if they persist due to futile repair cycles as a result of expanded fluoro(uracil) pools, ultimately leading to DNA breaks [199]. In addition to inhibition of TS and incorporation into DNA, fluoropyrimidine ribonucleotide triphosphates (5-FUTP) can be incorporated into nascent RNA molecules, perturbing a number of processes, including ribosomal RNA maturation and mRNA splicing $[204,205]$. The importance of RNA incorporation in the mechanism of action of fluoropyrimidines is underscored by numerous examples of treatment with exogenous uridine protecting cells from 5-FU cytotoxicity [206,207]. In fact, uridine is an FDA-approved rescue-treatment for overdose or severe toxicity with 5-FU or capecitabine [208]. All of these mechanisms likely contribute to therapeutic efficacy of fluoropyrimidines, however, despite decades of research, the relative contribution is still a topic of much debate.

It should be noted that (deoxy)adenosine analogues have also been reported to bind to purinergic receptors and exert agonistic or antagonistic activity that can modulate down-stream signalling. This suggests that at least a portion of nucleoside analogue-mediated toxicity might be due to engagement of the extracellular portion of membrane proteins, even though the practical implications remain elusive [209-212]. It is tempting to speculate whether nucleoside analogue di- and triphosphates, released during cell death, could mimic the antiproliferative effects of ATP and UTP via P2Y receptor engagement in bystander tumour cells [213].

Other nucleoside analogues exist in the clinical or pre-clinical setting that cannot be discussed in detail here. Tubercidin, toyocamycin, sangivamycin and derivatives are bacteria-derived adenosine analogues with different effects on RNA and DNA, protein kinase C, microtubules, and nucleophosmin (NPM1) [214-218]. These have been used in small clinical trials, in the case of tubercidin with clinical efficacy [219-224]. Importantly, differential resistance to these nucleoside analogues has been described in vitro [225]. Pentostatin, a purine analogue inhibiting adenosine deaminase (ADA), is used against hairy cell leukaemia [226]; ADA amplification is a resistance mechanism in vitro [9]. Testing a large set of patient chronic lymphocytic leukaemia (CLL) samples $(n=765)$, low cross-resistance of pentostatin with 2-F-ara-A was reported. Furthermore, in contrast to 2-F-ara-A and 2-CdA, treatment with pentostatin did not induce resistance and is therefore suggested to be a salvage agent for 2-F-ara-A-refractory CLL [227]. Forodesine, a guanosine analogue and inhibitor of purine nucleoside phosphorylase (PNP), exerts T-cell malignancy specific toxicity and does not seem to show cross-resistance to nelarabine [228], even though this has been suggested in resistant cell lines [229].

\section{Pharmacokinetic Resistance to Nucleobase/Nucleoside Analogues: Delivery}

\subsection{Bioavailability}

Nucleoside analogues like cytarabine (ara-C), 5-fluorouracil (5-FU) and gemcitabine (dF-dC) are characterised by low oral bioavailability and high first-pass effects in the liver $[230,231]$. Hence, these nucleobase/nucleoside analogues are usually administered parenterally to circumvent the digestive tract. Alternatively, lipophilic pro-drugs that require enzymatic conversion to the nucleoside analogue can have much higher oral bioavailability such as capecitabine, pro-drug of 5-FU [232], ara-C ocfosfate [233], pro-drug of ara-C, LY2334737, pro-drug of dF-dC [234], or sapacitabine, pro-drug of CNDAC [235]. On the other hand, a lack of hydrophilicity can critically affect water solubility and thereby achievable plasma concentrations that can be reached even when administering 
the drug intravenously, as is the case for arabinosylguanine (ara-G). Nelarabine, pro-drug of ara-G, achieves higher water solubility by addition of a methoxy group at the purine 6-carbon, which is subsequently converted into ara-G by ubiquitous adenosine deaminase (ADA). This made clinical application of ara-G possible decades after its discovery [236]. Similarly, fludarabine phosphate is a pro-drug for 2-F-ara-A with much higher water solubility, and is subsequently dephosphorylated by ubiquitous phosphates [237].

\subsection{Body Compartments as Sanctuaries}

The central nervous system (CNS), and other body compartments like the gonads $[238,239]$, maintain a barrier that tightly regulates accessibility of hydrophilic nucleoside analogues [240-245]. The efficacy of the blood-brain barrier (BBB) to shield the CNS from antimetabolites is historically best documented by children with ALL who-despite achieving complete remission when treated with antifolates [4] - almost universally relapsed with CNS disease. However, the BBB can be modulated by tumour-secreted signals, as illustrated by Wnt-positive medulloblastoma that has a better response to chemotherapy, as compared to other subtypes of medulloblastoma, due to a disrupted BBB [246]. To achieve clearance of cancer cells in the CNS, the BBB has to be circumvented either by changing the modality to radiation [247], intrathecal application of antimetabolites [248,249], or achieving effective antileukemic CNS concentrations using high-dose systemic regimens of methotrexate [250] or ara-C [251,252], as CNS concentrations of ara-C reach only $40 \%$ of plasma concentrations when administered intravenously $[230,253]$.

\section{Pharmacokinetic Resistance to Nucleobase/Nucleoside Analogues: Stability}

Apart from achieving therapeutically relevant peak concentrations of nucleobase/nucleoside analogues in the target tissue, maintenance of effective concentrations over longer periods of time is equally important, especially as these are typically S-phase specific drugs and the cell cycle of a population of tumour cells is asynchronous. However, catabolic enzymes degrade metabolites of nucleobase/nucleoside analogues and critically limit their biological half-life.

\subsection{Deamination}

Adenosine analogues are putative substrates for adenosine deaminase (ADA), which limits the clinical usefulness of vidarabine (ara-A) as an antineoplastic agent if not combined with the ADA inhibitor 2'-deoxycoformycin (pentostatin) [10]. However, 2-CdA, in fact initially developed as an ADA inhibitor, $\mathrm{Cl}-\mathrm{F}-$ ara-A, and 2-F-ara-A are, due to halogenation of their purine moiety with chlorine (2-CdA and Cl-F-ara-A) and fluorine (2-F-ara-A), intrinsically resistant to ADA [254].

Cytidine deaminase (CDA) in liver and plasma has broad nucleoside promiscuity and deaminates ara- $\mathrm{C}, \mathrm{dF}-\mathrm{dC}$, decitabine, azacitidine, and CNDAC to the much less potent metabolites arabinosyl-uridine (ara-U), difluorodeoxyuridine (dF-dU) [255], 5'-aza-deoxyuridine (aza-dU) [256], 5'-azauridine (aza-U) [256] and 2'-cyano-2'-deoxy-1- $\beta$-D-arabinopentofuranosyluracil (CNDAU) [235], respectively. Germ line polymorphisms of CDA exist that correlate with its enzymatic activity $[11,12]$. Whereas patients with a high CDA activity suffer from less adverse events following treatment with cytidine analogues, they are also at higher risk for disease progression due to a lack of efficacy as shown for dF-dC with pancreatic cancer [257], decitabine/azacitidine with myelodysplastic syndrome (MDS) [256], and ara-C with acute myeloid leukaemia (AML) [258,259]. A recent study confirmed a significantly higher rate of severe toxicities and death in 58 adult AML patients with lower CDA activity, but also indicated a tendency towards higher response rates [260]. Determination of polymorphisms with known consequences for CDA activity, ex vivo measurement of CDA activity and dose-adjustment following therapeutic drug monitoring (TDM) are warranted to reduce treatment failures due to germ-line resistance. CDA can be inhibited in vivo by the nucleoside analogues tetrahydrouridine (THU) and zebularine [18,19], however, longer exposure times for nucleoside analogues can also 
efficiently be achieved by protracted intravenous infusion, most extensively studied for ara-C [261], dF-dC [262], and 5-FU [263].

Even though CDA activity is largely absent in the cerebrospinal fluid [264], the half-life of ara-C after intrathecal application remains lower than therapeutically desirable; however, liposomal formulations of ara- $C$ can increase the half-life of ara- $C$ by up to two orders of magnitude $[265,266]$. Hence, it is clinically not sufficient to use drugs that have toxic efficacy against cancer; its formulation to tailor pharmacokinetics for optimal tumour exposure is at least equally important.

\subsection{Hydrogenation, Methylation, Deglycosylation}

5-FU is readily eliminated to $80 \%$ by plasma and liver dihydropyrimidine dehydrogenase (DPD) [267]. It is well studied that DPD activity correlates with the extent of 5-FU toxicity, and underlying polymorphisms in the DPYD gene have been characterised in detail $[55,56]$. As expected, despite a higher risk for toxicity, poor 5-FU metabolisers also benefit from better treatment outcomes [268,269]. Hence, both TDM [267,270] and inhibition of DPD with 5-chloro-2,4-dihydroxypyridine or eniluracil have been suggested to optimise treatment efficacy of 5-FU and capecitabine [57-59]. As DPD is also expressed in tumour cells, DPD inhibitors have also been suggested for cancers with high DPD expression [60].

The plasma half-life of TFT is largely determined by the catabolic activity of thymidine phosphorylase (TP, encoded by TYMP), removing its deoxyribose sugar moiety. Addition of tipiracil, a potent TP inhibitor, increases the area-under-the-curve for TFT by 37-fold [122]. Combination of TFT and tipiracil as a fixed oral combination has recently obtained FDA approval for metastatic colorectal cancer [123], and is particularly attractive as cross-resistance with other fluoropyrimidines is incomplete $[125,126]$.

Thiopurine S-methyltransferase (TPMT) is a ubiquitously expressed cytoplasmic enzyme that converts the thiopurines 6-thioguanine and 6-mercaptopurine into its less active methylated derivatives [271]. TPMT activity is routinely determined in erythrocytes in a clinical laboratory settings [272,273], and correlates with toxicity [274] and clinical outcomes [275] in leukaemia patients. There is a consistent genotype-phenotype relationship of TPMT germ line variants, even though its clinical relevance is debated [119]. Interestingly, the xanthine oxidase inhibitor allopurinol leads to functional inhibition of TPMT, possibly through the production of thioxanthine [120]. Recently, DNA-thioguanine nucleotide concentrations have been suggested as a measure for TDM for thiopurine therapy [276], overcoming resistance by dose-adjustments.

\section{Tumour-Specific Resistance to Nucleobase/Nucleoside Analogues: Membrane Transport}

Nucleoside analogues are principally transported by two membrane transporter families: SLC28, human concentrative nucleoside transporters (hCNT1-3), and SLC29, human equilibrative nucleoside transporters (hENT1-4) [277,278]. hCNTs, with the exception of hCNT3 [279], are expressed in a tissue-restricted manner, mainly in intestinal and renal epithelia, and transport nucleosides in a monodirectional sodium- or hydrogen-dependent manner with specificity for pyrimidines (hCNT1), purines (hCNT2), or both (hCNT3). hENT1-3 are ubiquitously expressed, and hENT4 is mainly present in brain and heart $[243,277,280]$. Whereas nucleobases like thiopurines and 5-FU can only be transported by hENTs, nucleoside analogues can be transported both by hENTs and hCNTs (an overview of transporter affinity for individual nucleoside analogues can be found here: [278]). As hENTs are bidirectional transporters, the hENT inhibitors nitrobenzylthioinosine (NBMPR) and dipyridamole can inhibit efflux of intracellular nucleoside analogues as demonstrated for 2-CdA [88]. This might be a strategy to increase intracellular exposure to nucleoside analogues when administered sequentially or when influx is primarily mediated by hCNTs [278]. Expression of hENTs has furthermore been positively correlated with in vitro sensitivity to 2-CdA, ara-C and dF-dC [74-77]. More importantly, hENT1 expression also correlated positively with survival in pancreatic cancer and gallbladder adenocarcinoma patients treated with $\mathrm{dF}-\mathrm{dC}[78,79]$, as did expression of hENT3 [80]. 
Similar observations were made in metastatic colorectal cancer treated with trifluridine/tipiracil [81]. When taking into account both hENT1 and hCNT3 expression, high expression of both was strongly associated with improved survival in pancreatic cancer treated with $\mathrm{dF}-\mathrm{dC}$, underlining the importance of membrane transport for therapy efficacy [281]. In addition, single nucleotide polymorphisms (SNPs) for nucleoside transporters exist that correlate both with toxicity and therapeutic efficacy of $\mathrm{dF}-\mathrm{dC}$ in pancreatic cancer [82]. Similar roles of expression levels as well as polymorphisms have been reported for ara-C in the treatment of AML [83-87]. More recently, alternative transport mechanisms for ara-C and $\mathrm{dF}-\mathrm{dC}$, involving the SLC22 family, have been described, correlating with overall survival of AML patients treated with ara-C [282].

Purine analogues like 6-TG can be exported by multidrug resistance protein 4 (MRP4), also called ATP-binding cassette transporter 4 (ABCC4) [283], and a SNP in ABCC3 has been correlated with adverse prognosis in AML patients [83]. Similarly, expression of ABCC11 negatively correlated with overall survival in AML [284]. In thiopurine-resistant T-ALL cell lines, down-regulation of hENT2 and hCNT3 was identified [70]. More about the role of ABC transporters for resistance to nucleoside analogues can be found elsewhere [285].

Several approaches exist to overcome dependency on membrane transport proteins for cellular delivery of nucleoside analogues. The elaidic acid ester derivative of ara-C, elacytarabine, is designed to cross the plasma membrane with its lipophilic tail [71] and has been introduced in phase-II and III trials, albeit with modest results [72,73].

\section{Tumour-Specific Resistance to Nucleobase/Nucleoside Analogues: Intracellular Metabolism}

\subsection{Glycosylation of Nucleobases}

Unlike nucleoside analogues, the thiopurine nucleobases and 5-FU need to be glycosylated by means of purine salvage and pyrimidine salvage pathways, respectively. 5-FU can be transformed into 5-F-uridine (5-FUrd) or 5-F-2'-deoxyuridine (5-FdUrd) by uridine phosphorylase 1 (UP1) or TP, respectively [286]. Alternatively, 5-FU can be directly converted into 5-FUrd monophosphate (5-FUMP) by uridine monophosphate synthetase (UMPS, harbouring orotate phosphoribosyl-transferase activity) [286]. In certain cell lines, up-regulation of UP1 leads to increased 5-FU efficacy [136], however, in a cohort of 43 patients with gastric cancer, high expression of UP1 was associated with worse overall survival [287]. In addition, the effects of UP1 inhibitors on 5-FU toxicity are cell-line dependent and can both decrease and increase the efficacy of 5-FU as shown for three different colon cancer cell lines [137], possibly reflecting that the relative contribution mediated by different 5-FU metabolites depends on the cellular background. This is further complicated by the fact that UP1 also catalyses conversion of 5-FdUrd to 5-FU [288]. A Chinese meta-analysis found a positive correlation of TP expression and relapse-free and overall survival of colorectal cancer patients treated with 5-FU [121]. Use of another class of cytotoxic drugs, taxanes, that increases expression of TP, have been suggested as combination therapies to improve 5-FU efficacy [124]. Interestingly, TP has also been reported as a driver of tumour proliferation and metastasis [289], illustrating that nucleoside analogue metabolising enzymes can be double-edged swords, as reported for SAMHD1 [118]. In a 5-FU resistant cell line, UMPS down-regulation was identified [135], whereas experimental overexpression of UMPS increased toxicity of 5-FU in vitro [290,291], and the ratio of UMPS-to-DPD expression has been associated with better overall survival in a Japanese cohort of 5-FU-treated patients with colorectal cancer [292]. High UMPS expression was confirmed to correlate with patient survival in another colorectal cancer cohort [293] as well as in patients with oesophageal squamous cell carcinoma [294]. To the best of our knowledge, associations with UMPS polymorphisms have only been reported for toxicity to 5-FU [295], but not for efficacy.

Hypoxanthine guanosine phosphoribosyltransferase (HGPRT, encoded by HPRT1) converts the thiopurines 6-MP and 6-TG into 6-thioinosine monophosphate (TIMP) and 6-thioguanosine monophosphate (TGMP), respectively, and TIMP can be further metabolised into thioxanthosine 
monophosphate (TXMP) and TGMP by inosine monophosphate dehydrogenase (IMPDH) and guanosine monophosphate synthetase (GMPS), respectively [296]. A Dutch study in paediatric patients showed that lower HGPRT activity correlated with poorer prognosis in precursor B-acute lymphoblastic leukaemia (pre-B-ALL), even though no correlation was found with in vitro 6-TG resistance [89]. Another study suggested lower expression of HGPRT to be putatively associated with worse therapy outcome in ALL [90]. Allopurinol, an inhibitor of xanthine oxidase, has been reported or suggested to increase HGPRT activity in patients with inflammatory bowel disease (IBD) and ALL [91,92]. In the myeloid cell line HL-60, acquired mutations in the HPRT1 gene were detected in half of 6-TG-resistant clones evaluated [297]. Less is known about the role of IMPDH for thiopurine resistance. However, azathioprine (which is extracellularly converted to 6-MP) resistance in one patient with IBD was mediated by an IMPDH1 promoter mutation negatively affecting transcription [93], suggestive that loss or reduction of IMPDH activity is a possible mechanism of resistance even in cancer patients treated with thiopurines. As for GMPS, its expression was reported to be down-regulated in a thiopurine-resistant T-cell line as compared to the parental cell line [69], but the clinical significance of GMPS warrants further investigation.

\subsection{Monophosphorylation}

Deoxycytidine kinase $(\mathrm{dCK})$ is the principal kinase to activate both pyrimidine and purine nucleoside analogues, however, adenosine kinase, to a lesser extent, has been reported to contribute to purine nucleoside phosphorylation as shown for ara-A [298], although its relevance has been questioned [299]. At least in cell lines and in ex vivo patient-derived primary mantle cell lymphoma cells, downregulation of dCK was not only associated with resistance to ara-C, but also to dF-dC, 2-F-ara-A, and 2-CdA, but not to non-antimetabolic cytotoxic drugs [37]. These findings were confirmed in an independent study [38]. Another study found a correlation of cytotoxic response to decitabine and $\mathrm{dF}-\mathrm{dC}$ in breast cancer cell lines; interestingly, the same report also identified higher $\mathrm{dCK}$ expression in breast cancer tissue from patients with poor outcome as compared to patients with good outcome [39]. Hence, downregulation of dCK, albeit a possible mechanism for resistance to nucleoside analogues ex vivo, might clinically be less relevant as this might be associated with decreased fitness and proliferative potential in vivo. This is corroborated by the finding that reduced dCK expression can lead to sensitisation to corticosteroids in AML, both in cell lines and in patients [40,41]; furthermore, the absence of mutations in DCK in relapsed and refractory AML patients argues against that loss of dCK expression in resistant cell lines adequately recapitulates treatment-related resistance [42]. Nevertheless, an earlier study reported that alternative splicing might result in reduced dCK activity in patients with resistant AML [43], and cell lines derived from a patient before and after high-dose ara-C therapy showed reduced dCK expression in two resistant cell clones post therapy [300]. In addition, out of seven patients with ara-C-resistant AML, five showed low activity of dCK [301]. Eventually, polymorphisms in DCK can be associated with prognosis in paediatric AML [44] as well as toxicity to ara-C in paediatric ALL [45]. Interestingly, etoposide, a cytotoxic topoisomerase II inhibitor that is routinely combined with ara-C and anthracyclines in paediatric AML treatment, was reported to increase dCK activity [46].

Deoxyguanosine kinase (DGK, encoded by DGUOK) activity might marginally contribute to the overall toxicity of purine nucleoside analogues as evidenced in the case of $\mathrm{Cl}-\mathrm{F}$-ara-A in dCK-deficient cell lines [52], concomitant reduction of both dCK and dGK in an ara-G-resistant cell line [53], and for 2-CdA and ara-G in dGK overexpression experiments [54]. DGK is-due to its mitochondrial localisation-an interesting candidate to explain S-phase-independent effects of Cl-F-ara-A [302].

Thymidine nucleoside analogues are activated by cytosolic thymidine kinase (TK1). In a colorectal cancer cell line, loss of TK1 expression confers resistance to trifluridine, but retains full sensitivity to 5-FU [34], even though TK1 is critical for phosphorylation of the 5-FU-derivative 2'-deoxy-5-fluorouridine (5-FdU) [303] which-however-can be circumvented by RNR-mediated reduction of 5-FU diphosphate (5-FUDP) to 5-FdUDP. Even though mitochondrial TK2 can 
phosphorylate ara-C [304], its role for the efficacy of nucleoside analogue therapy remains elusive. On the other hand, nucleosidic inhibitors of TK2 have been suggested as S-phase independent anticancer agents [305].

To overcome deficiency in monophosphorylation as a mechanism of resistance, intracellular delivery of nucleoside analogue phosphates has been suggested. However, due to the high polarity of phosphates and the absence of efficient membrane transport proteins, medicinal chemistry has to be employed to cross the plasma membrane-with similar approaches used to overcome transport deficiency of nucleoside analogues (see above). Aryloxy phosphoramidate triester pro-drugs of nucleoside analogue monophosphates (so called ProTides or pro-tides) allow transporter-independent translocation across the plasma membrane and circumvent the need of phosphorylation by dCK [16,47], and antivirals using this technology have entered the clinic [48]. Phosphoramidates of ara-C and $\mathrm{dF}-\mathrm{dC}$ have been developed and evaluated pre-clinically, the latter of which having entered a phase-I/II clinical trial $[49,50]$. Murine L1210 cells resistant to ara-C and dF-dC due to loss of dCK expression were still sensitive to a pro-tide of ara-C [51], being a proof-of-concept for this approach. Other medicinal chemistry strategies of lipophilising nucleoside analogue monophosphates [306] and di- and triphosphates exist, but have not yet entered the clinic due to a variety of problems [101].

\subsection{Diphosphorylation}

UMP/CMP kinase (UCK, encoded by CMPK1) is responsible for phosphorylation of cytidine and uridine analogue monophosphates [307,308]. Decreased levels of UCK have been suggested as a mechanism of fluoropyrimidine resistance based on mRNA expression studies in material from colorectal cancers with clinical resistance to 5-FU [132]. In addition, analysis of 80 xenograft models revealed that expression of CPMK1 is predictive for 5-FU sensitivity [309]. Polymorphisms of CMPK1 were associated with overall survival of 102 pancreatic cancer patients and lung cancer patients treated with $\mathrm{dF}-\mathrm{dC}[133,134]$. Hence, assessment of CPMK1 status could add information for personalised antimetabolite treatments.

Another monophosphate kinase, mitochondrial UMP/CMP kinase 2, is able to phosphorylate dF-dCMP, but its role for chemotherapy remains to be elucidated [310]. Apart from its suggested role for TFT monophosphate phosphorylation [311], the role of TMP kinase (TMPK) for treatment with nucleoside analogues is largely elusive as its expression-in contrast to CMPK1-did not independently correlate with 5-FU sensitivity in xenograft models [309]. Surprisingly, the monophosphate kinase(s) responsible for generation of purine nucleoside analogue diphosphates are not identified nor further characterised.

\subsection{Triphosphorylation}

Nucleotide diphosphate kinase 1 and 2 (NDPK1/2, encoded by NME1/2) are supposed to be responsible for catalysis of the last phosphorylation step leading to active triphosphates of virtually all clinically used nucleobase and nucleoside analogues. Whereas polymorphisms in NME1 correlated with toxicity in AML patients treated with ara-C, no correlation was found with efficacy measures in a cohort of 360 Caucasian patients [99]. A study in Chinese AML patients could not identify a significant correlation of NME1 SNPs with clinical response, but revealed a significant correlation of a SNP in NME2 with complete response [100]. Interpretation of these results, however, is difficult, as NME1 expression has been reported to correlate with poor prognosis in AML [312,313], and NDPK2 harbours tumour suppressor functions [314].

\subsection{Intracellular Deamination}

CDA and ADA are also expressed in tumour cells. In addition, dCMP deaminase (DCTD) deaminates monophosphates of cytidine analogues. Whereas the ADA-mediated block to efficacy of adenosine analogues has been overcome by introduction of ADA-resistant analogues (see above), CDA is a possible driver of resistance to nucleoside analogues [315]. It has been reported that 
ex vivo toxicity of $\mathrm{dF}-\mathrm{dC}$ and decitabine correlated negatively with mRNA expression of CDA in primary leukemic blasts from children with AML [316]. A CDA-resistant ara-C-derivative has shown pre-clinical efficacy $[317,318]$, as has a pro-tide derivative of dF-dC [49]. Furthermore, inhibition of CDA with zebularine increased efficacy of ara-C in a murine leukaemia model [19]. However, changes in $C D A$ expression in vivo following relapse after ara- $C$ treatments have not been identified $[84,300,319]$. Nevertheless, it has been hypothesised that $C D A$ expression contributes to the intrinsic resistance of solid tumours to ara-C [17]. Polymorphisms of $C D A$ exist that correlate with ara-C sensitivity [13], and survival in ara-C-treated AML patients [14] as well as dF-dC-treated ovarian cancer patients [15]. 5-fluorodeoxycytidine has been suggested as a CDA inhibitor, and, following monophosphorylation, as an inhibitor of DCTD [35,36]. In addition, a SNP has been described that affects deaminase activity towards dF-dCMP [320]. However, intratumoural expression of DCTD was not prognostic in a European patient cohort with pancreatic cancer treated with dF-dC [321]. Eventually, it should be noted that even deaminated nucleoside analogues might harbour some activity, even though this is not well studied [322].

\subsection{Dephosphorylation of Monophosphates}

The pool of active metabolites of nucleobase/nucleoside analogues can be limited by the action of dephosphorylating enzymes, with cytosolic $5^{\prime}$-nucleotidase I, II and III (cN-I/II/III encoded by $N T 5 C 1 / 2 / 3$ ) cleaving monophosphates of nucleoside analogues. Among the cytosolic nucleotidases, cN-II has been studied most extensively. Overexpression of NT5C2 leads to decreased sensitivity to ara-C, dF-dC, 2-F-ara-A, Cl-F-ara-A and 2-CdA [20,21]. The mRNA expression levels of NT5C2 were associated with adverse clinical outcome in adult AML patients treated with ara-C [22], and, when combined with expression levels of $D C K$, negatively correlated with accumulation of ara-CTP in primary paediatric AML cells, and ara-C sensitivity in AML cell lines [23-25]. In lung cancer patients treated with $\mathrm{dF}-\mathrm{dC}$, protein expression of $\mathrm{cN}-\mathrm{II}$ was significantly correlated with overall survival [26]. Gain-of-function mutations in NT5C2 can be found in relapsed ALL patients and leads to 6-mercaptopurine resistance in mouse models of ALL [20,28-31]. Eventually, polymorphisms of NT5C2 that correlate with decreased survival in paediatric and adult AML have been described [14,32].

NT5C3 expression and polymorphisms have been associated with in vitro efficacy of dF-dC and ara-C [323], and a SNP correlating with NT5C3 expression was associated with the rate of complete response in AML patients treated with ara-C [33]. Overexpression of NT5C1 conferred resistance to ara-C, 2-CdA, dF-dC, 2-F-ara-A and 5-FU in cell lines [27]. Currently, no inhibitor of cytosolic nucleotidases exists, but lipophilic pro-drugs of nucleoside analogue diphosphates and triphosphates could circumvent the step of monophosphorylation and thereby deprive nucleotidases of their substrates [101].

\subsection{Dephosphorylation of Triphosphates}

For many nucleobase/nucleoside analogues, it is the triphosphate metabolite that is responsible for clinical efficacy. Thus, enzymes which directly modulate the intracellular triphosphate pools, of which there are many [324], can play critical roles in modulating treatment efficacy.

Expression of the dUTP diphosphatase, dUTPase, negatively correlates with therapy response to 5-FU, which could either be mediated by reduced dUTP accumulation following TS inhibition [63], or by reduced accumulation of the 5-FU active metabolite 5-F-dUTP [64], see above. Similarly, overexpression of dUTPase reduces the efficacy of decitabine by reducing the pools of 5-aza-dCTP and 5-aza-dUTP, which also leads to an increase in 5-aza-dUMP possibly resulting in additional inhibition of TS [325,326]. Consistently, inhibitors of dUTPase have been reported to increase the efficacy of 5-FU [65-67]. A dual inhibitor of DPD and dUTPase has been shown to increase the antineoplastic effects of capecitabine towards a human breast cancer xenograft in mice [68]. Interestingly, pre-treatment of a colon-cancer cell line with oxaliplatin decreased dUTPase expression and increased sensitivity to 5-FU [327]. A related pyrophosphatase, dCTPase (also called DCTPP1), 
has been shown to reduce the efficacy of $\mathrm{dF}-\mathrm{dC}$ and decitabine in leukemic cell lines $[63,328]$, and a number of pre-clinical inhibitors for dCTPase have been reported [328,329].

The nucleotide diphosphatase NUDT15, a member of nudix hydrolase family, possesses activity towards a selection of canonical nucleotides and their oxidised variants, and has been proposed to have a role in dNTP pool sanitation [324]. A missense mutation of NUDT15, R139C, in patients of Asian descent, was found to significantly correlate with thiopurine intolerance in ALL and IBD patients [330-332]. Shortly after this finding, NUDT15 was demonstrated to possess hydrolytic activity towards the active triphosphate metabolites of thiopurines, 6-thio-(d)GTP [98], and accordingly, control cytotoxicity of this analogue in cancer cell models $[333,334]$. The NUDT15 R139C variant was shown to affect protein stability [334], and in line with this, patients with this mutation, and others resulting in defective NUDT15, had increased levels of thiopurine active metabolites and accompanying toxicity [333]. Personalised thiopurine therapy could circumvent these problems, and with this in mind, a recent study utilised a novel NUDT15 knockout mouse model to demonstrate the feasibility of NUDT15 genotype-guided dose individualisation. This study effectively showed that, using this strategy, drug toxicity could be prevented while maintaining therapy efficacy [335].

Inosine triphosphatase (ITPA) is a pyrophosphatase regulating sanitation of the endogenous non-canonical (deoxy)nucleotide triphosphates (deoxy)inosine, and (deoxy)xanthosine triphosphate, that can also use 6-thio-ITP as a substrate [336-338]. Polymorphisms in ITPA have been described to correlate with intolerance to mercaptopurine treatment in IBD [339], even though these results have been questioned in a later meta-analysis [340]. As 6-thio-ITP is a direct substrate for TPMPT, reducing the thiopurine nucleotide pool that can be used as a substrate for DNA polymerases, activity of ITPA shifts metabolism of thiopurines towards metabolites that can be incorporated into DNA. Accordingly, an ITPA polymorphism has been shown to correlate with levels of methylated thiopurine metabolites in 66 children with ALL [94], levels of 6-TG incorporation into DNA in 132 ALL patients, and is a factor highly likely to influence outcome of ALL patients treated with thiopurines [95]. Furthermore, this ITPA SNP was associated with toxicity [96] and treatment outcome in a British ALL cohort [97].

In 2015, it was shown that the dNTP triphosphohydrolase SAMHD1—a protein heavily involved in the evolution the human immunodeficiency virus [341], and the only known eukaryotic enzyme that can cleave nucleotide triphosphates to nucleosides and inorganic triphosphate-is able to hydrolyse Cl-F-ara-ATP [342]. We and others have subsequently shown that other nucleoside analogue triphosphates are substrates or substrate candidates for SAMHD1, in particular ara-CTP, ara-GTP, 5-aza-dCTP, and ara-ATP [117,118,343-345]. Furthermore, we could show that expression levels of SAMHD1 correlate with event-free and overall survival, but, importantly, not with complete remission, of adult and paediatric AML patients treated with ara-C $[117,118]$. We have suggested the use of the viral protein $X(\mathrm{Vpx})$ as a strategy to inhibit SAMHD1 activity towards nucleoside analogue triphosphates [117], and the development of in vitro and cell-active small molecule inhibitors of SAMHD1 is underway [346-348].

\section{Tumour-Specific Resistance to Nucleobase/Nucleoside Analogues: Pharmacodynamics}

Overexpression of the targets of nucleoside analogue active metabolites is one mechanism to mitigate and escape toxicity, as evidenced extensively for RNR in cell lines [103-106], mouse models of colon cancer [107] and patient material [108-114]. Furthermore, polymorphisms of the RRM1 promoter correlated with clinical response to $\mathrm{dF}-\mathrm{dC}$ in non-small cell lung cancer patients [115]. Inhibitors of the MEK-ERK signalling pathway have been shown to increase $\mathrm{dF}-\mathrm{dC}$ sensitivity by reducing RNR expression [349]. Analogous to RNR, overexpression of TYMS, the gene encoding TS, can lead to resistance to TS inhibitors, in particular fluoropyrimidines, both in vitro [116,127-129] and in patients [130]. Histone deacetylase inhibitors have been shown to reduce TYMS expression and thereby synergise with fluoropyrimidines [128,350]. Along these lines, increased activity and expression of DNMT1 is a possible mechanism for decitabine resistance whereas DNMT3A mutations 
lead to increased efficacy of decitabine [61,102]. Also increased activity of PPAT, inhibited by thiopurine monophosphates, is a possible mechanism of resistance to these groups of nucleobase analogues [131]. Future studies will have to elucidate the contribution of expression levels of DNA glycosylases/BER and DNA mismatch repair [351] components to fluoropyrimidine resistance.

\section{Tumour-Specific Resistance to Nucleobase/Nucleoside Analogues: Tumour Biology}

Eventually, even if high levels of active metabolites can be achieved intracellularly, and even if the pharmacodynamic targets can be sufficiently antagonised, the efficacy of nucleoside and nucleobase analogues is not guaranteed. A recent study showed that ara-C-resistant cells can actually incorporate much higher amounts of an ara-C-derivative, $\mathrm{AzC}$, that is amenable for super-resolution microscopy, into DNA as compared to ara-C-sensitive cells without leading to cell death. Instead, AzC incorporation led to highly stable stalled replication forks, and DNA replication was resumed once $\mathrm{AzC}$ was removed from the medium. Furthermore, AzC was detectable in daughter-cell DNA [352]. Hence, modulation of down-stream effectors responding to stalled replication forks and DNA-damage are likely to be responsible for ara-C resistance in this context. Tumour evolution can be driven by the loss of tumour suppressors. Not surprisingly, loss of factors that control DNA integrity limit cytotoxicity of nucleoside analogues, as shown for p53 [353,354] and Schlafen 11 (SLFN11) [355]. Strategies to reactivate p53 or target mutant p53 [356,357] and SLFN11 via histone deacetylase or EZH2 inhibition are under development $[358,359]$.

\section{Clinical Resistance to Nucleobase/Nucleoside Analogues: Therapy-Limiting Toxicity}

Nucleoside analogues are S-phase, but not tumour-specific drugs, and will therefore exert toxic effects in proliferative normal tissues. In vitro, resistance to a nucleobase or nucleoside analogue is usually a relative measure, indicated by highly increased concentrations to achieve killing of cancer cells in comparison to sensitive cancer cells. Translated into the clinic, this usually means that these concentrations could not be achieved in vivo due to therapy-limiting toxicities. In other words, clinical resistance can be interpreted as a therapeutic window of zero (or below), which means that concentrations necessary to cure the cancer cannot be reached due to unacceptable toxicities. Comparing expression levels of key factors involved in transport, metabolism and drug effector functions in tissues at risk with the tumour, informs about the breadth of the therapeutic window. Capecitabine is a prime example where differential expression of the activating enzyme TP correlates with an increased therapeutic window due to selective accumulation of 5-FU [360].

\section{Conclusions}

Curing cancer with chemotherapy has been possible since the 1960's, and the necessity of combination chemotherapy is evident. Nucleobase and nucleoside analogues are an important class of anti-cancer drugs for solid and haematological malignancies. Understanding the clinical and molecular determinants of chemotherapeutic efficacy is paramount for further treatment improvements. As lack of efficacy can be caused at a pharmacokinetic, a metabolic and a pharmacodynamic level, and be further complicated by the underlying intrinsic tumour biology, a multitude of possible treatment modulations, or change of therapy modality altogether, exist. However, understanding the net consequence of patient- and tumour-specific predictors of therapy outcome is an immense task. We nevertheless believe that nucleoside analogues are ready to enter the era of precision medicine [361].

Author Contributions: The review was conceptualised by N.H. The text was written by S.G.R. and N.H. and the figures and tables were made by all authors. All authors reviewed, commented and edited the manuscript.

Funding: This work was supported the Swedish Children's Cancer Foundation (TJ2017-0021 (to S.G.R.); TJ2016-0040 and PR2016-0044 (to N.H.)), the Swedish Cancer Society (CAN 2017/517 to N.H.), the Stockholm County Council (ALF) (K2892-2016 to N.H), the Clas Groschinsky Memorial Foundation (M18228 to N.H.), the Alex and Eva Wallström Foundation for scientific research and education (2017-00475 and 2018-00109 to 
S.G.R.), the Felix Mindus contribution to Leukemia Research (2016-52575 and 2017-01287 to S.G.R.), and Karolinska Institutet Foundations (2016-50273 to S.G.R.; and 2016-50756 to N.H.).

Acknowledgments: We are grateful to J.-I. Henter and T. Helleday for scientific support, and thank N.C.K. Valerie and T. Schaller for scientific discussions.

Conflicts of Interest: The authors declare no conflict of interest.

\section{References}

1. Steeg, P.S. Targeting metastasis. Nat. Rev. Cancer 2016, 16, 201-218. [CrossRef] [PubMed]

2. Majzner, R.G.; Heitzeneder, S.; Mackall, C.L. Harnessing the Immunotherapy Revolution for the Treatment of Childhood Cancers. Cancer Cell 2017, 31, 476-485. [CrossRef] [PubMed]

3. Gotwals, P.; Cameron, S.; Cipolletta, D.; Cremasco, V.; Crystal, A.; Hewes, B.; Mueller, B.; Quaratino, S.; Sabatos-Peyton, C.; Petruzzelli, L.; et al. Prospects for combining targeted and conventional cancer therapy with immunotherapy. Nat. Rev. Cancer 2017, 17, 286-301. [CrossRef] [PubMed]

4. Farber, S.; Diamond, L.K. Temporary remissions in acute leukemia in children produced by folic acid antagonist, 4-aminopteroyl-glutamic acid. N. Engl. J. Med. 1948, 238, 787-793. [CrossRef] [PubMed]

5. Kisliuk, R.L. Synergistic interactions among antifolates. Pharmacol. Ther. 2000, 85, 183-190. [CrossRef]

6. Shimizu, T.; Nakanishi, Y.; Nakagawa, Y.; Tsujino, I.; Takahashi, N.; Nemoto, N.; Hashimoto, S. Association between expression of thymidylate synthase, dihydrofolate reductase, and glycinamide ribonucleotide formyltransferase and efficacy of pemetrexed in advanced non-small cell lung cancer. Anticancer Res. 2012, 32, 4589-4596. [PubMed]

7. Bertino, J.R. Cancer research: From folate antagonism to molecular targets. Best Pract. Res. Clin. Haematol. 2009, 22, 577-582. [CrossRef] [PubMed]

8. Curtin, N.J.; Hughes, A.N. Pemetrexed disodium, a novel antifolate with multiple targets. Lancet Oncol. 2001, 2, 298-306. [CrossRef]

9. Rowland, P., 3rd; Pfeilsticker, J.; Hoffee, P.A. Adenosine deaminase gene amplification in deoxycoformycin-resistant mammalian cells. Arch. Biochem. Biophys. 1985, 239, 396-403. [CrossRef]

10. Agarwal, R.P.; Blatt, J.; Miser, J.; Sallan, S.; Lipton, J.M.; Reaman, G.H.; Holcenberg, J.; Poplack, D.G. Clinical pharmacology of 9-beta-D-arabinofuranosyladenine in combination with 2'-deoxycoformycin. Cancer Res. 1982, 42, 3884-3886. [PubMed]

11. Serdjebi, C.; Milano, G.; Ciccolini, J. Role of cytidine deaminase in toxicity and efficacy of nucleosidic analogs. Expert Opin. Drug Metab. Toxicol. 2015, 11, 665-672. [CrossRef] [PubMed]

12. Parmar, S.; Seeringer, A.; Denich, D.; Gartner, F.; Pitterle, K.; Syrovets, T.; Ohmle, B.; Stingl, J.C. Variability in transport and biotransformation of cytarabine is associated with its toxicity in peripheral blood mononuclear cells. Pharmacogenomics 2011, 12, 503-514. [CrossRef] [PubMed]

13. Yue, L.; Saikawa, Y.; Ota, K.; Tanaka, M.; Nishimura, R.; Uehara, T.; Maeba, H.; Ito, T.; Sasaki, T.; Koizumi, S. A functional single-nucleotide polymorphism in the human cytidine deaminase gene contributing to ara-C sensitivity. Pharmacogenetics 2003, 13, 29-38. [CrossRef] [PubMed]

14. Falk, I.J.; Fyrberg, A.; Paul, E.; Nahi, H.; Hermanson, M.; Rosenquist, R.; Hoglund, M.; Palmqvist, L.; Stockelberg, D.; Wei, Y.; et al. Decreased survival in normal karyotype AML with single-nucleotide polymorphisms in genes encoding the AraC metabolizing enzymes cytidine deaminase and $5^{\prime}$-nucleotidase. Am. J. Hematol. 2013, 88, 1001-1006. [CrossRef] [PubMed]

15. Tibaldi, C.; Giovannetti, E.; Tiseo, M.; Leon, L.G.; D’Incecco, A.; Loosekoot, N.; Bartolotti, M.; Honeywell, R.; Cappuzzo, F.; Ardizzoni, A.; et al. Correlation of cytidine deaminase polymorphisms and activity with clinical outcome in gemcitabine-/platinum-treated advanced non-small-cell lung cancer patients. Ann. Oncol. 2012, 23, 670-677. [CrossRef] [PubMed]

16. Cahard, D.; McGuigan, C.; Balzarini, J. Aryloxy phosphoramidate triesters as pro-tides. Mini Rev. Med. Chem. 2004, 4, 371-381. [CrossRef] [PubMed]

17. Ohta, T.; Hori, H.; Ogawa, M.; Miyahara, M.; Kawasaki, H.; Taniguchi, N.; Komada, Y. Impact of cytidine deaminase activity on intrinsic resistance to cytarabine in carcinoma cells. Oncol. Rep. 2004, 12, 1115-1120. [CrossRef] [PubMed] 
18. Kreis, W.; Budman, D.R.; Chan, K.; Allen, S.L.; Schulman, P.; Lichtman, S.; Weiselberg, L.; Schuster, M.; Freeman, J.; Akerman, S.; et al. Therapy of refractory/relapsed acute leukemia with cytosine arabinoside plus tetrahydrouridine (an inhibitor of cytidine deaminase)—A pilot study. Leukemia 1991, 5, 991-998. [PubMed]

19. Lemaire, M.; Momparler, L.F.; Raynal, N.J.; Bernstein, M.L.; Momparler, R.L. Inhibition of cytidine deaminase by zebularine enhances the antineoplastic action of 5-aza-2'-deoxycytidine. Cancer Chemother. Pharmacol. 2009, 63, 411-416. [CrossRef] [PubMed]

20. Cividini, F.; Filoni, D.N.; Pesi, R.; Allegrini, S.; Camici, M.; Tozzi, M.G. IMP-GMP specific cytosolic 5'-nucleotidase regulates nucleotide pool and prodrug metabolism. Biochim. Biophys. Acta 2015, 1850, 1354-1361. [CrossRef] [PubMed]

21. Jordheim, L.P.; Marton, Z.; Rhimi, M.; Cros-Perrial, E.; Lionne, C.; Peyrottes, S.; Dumontet, C.; Aghajari, N.; Chaloin, L. Identification and characterization of inhibitors of cytoplasmic $5^{\prime}$-nucleotidase $\mathrm{cN}-\mathrm{II}$ issued from virtual screening. Biochem. Pharmacol. 2013, 85, 497-506. [CrossRef] [PubMed]

22. Galmarini, C.M.; Cros, E.; Thomas, X.; Jordheim, L.; Dumontet, C. The prognostic value of cN-II and cN-III enzymes in adult acute myeloid leukemia. Haematologica 2005, 90, 1699-1701. [PubMed]

23. Negoro, E.; Yamauchi, T.; Urasaki, Y.; Nishi, R.; Hori, H.; Ueda, T. Characterization of cytarabine-resistant leukemic cell lines established from five different blood cell lineages using gene expression and proteomic analyses. Int. J. Oncol. 2011, 38, 911-919. [PubMed]

24. Galmarini, C.M.; Thomas, X.; Graham, K.; El Jafaari, A.; Cros, E.; Jordheim, L.; Mackey, J.R.; Dumontet, C. Deoxycytidine kinase and $\mathrm{cN}-\mathrm{II}$ nucleotidase expression in blast cells predict survival in acute myeloid leukaemia patients treated with cytarabine. Br. J. Haematol. 2003, 122, 53-60. [CrossRef] [PubMed]

25. Yamauchi, T.; Negoro, E.; Kishi, S.; Takagi, K.; Yoshida, A.; Urasaki, Y.; Iwasaki, H.; Ueda, T. Intracellular cytarabine triphosphate production correlates to deoxycytidine kinase/cytosolic $5^{\prime}$-nucleotidase II expression ratio in primary acute myeloid leukemia cells. Biochem. Pharmacol. 2009, 77, 1780-1786. [CrossRef] [PubMed]

26. Seve, P.; Mackey, J.R.; Isaac, S.; Tredan, O.; Souquet, P.J.; Perol, M.; Cass, C.; Dumontet, C. cN-II expression predicts survival in patients receiving gemcitabine for advanced non-small cell lung cancer. Lung Cancer 2005, 49, 363-370. [CrossRef] [PubMed]

27. Hunsucker, S.A.; Spychala, J.; Mitchell, B.S. Human cytosolic 5'-nucleotidase I: Characterization and role in nucleoside analog resistance. J. Biol. Chem. 2001, 276, 10498-10504. [CrossRef] [PubMed]

28. Hnizda, A.; Fabry, M.; Moriyama, T.; Pachl, P.; Kugler, M.; Brinsa, V.; Ascher, D.B.; Carroll, W.L.; Novak, P.; Zaliova, M.; et al. Relapsed acute lymphoblastic leukemia-specific mutations in NT5C2 cluster into hotspots driving intersubunit stimulation. Leukemia 2018, 32, 1393-1403. [CrossRef] [PubMed]

29. Meyer, J.A.; Wang, J.; Hogan, L.E.; Yang, J.J.; Dandekar, S.; Patel, J.P.; Tang, Z.; Zumbo, P.; Li, S.; Zavadil, J.; et al. Relapse-specific mutations in NT5C2 in childhood acute lymphoblastic leukemia. Nat. Genet. 2013, 45, 290-294. [CrossRef] [PubMed]

30. Tzoneva, G.; Dieck, C.L.; Oshima, K.; Ambesi-Impiombato, A.; Sanchez-Martin, M.; Madubata, C.J.; Khiabanian, H.; Yu, J.; Waanders, E.; Iacobucci, I.; et al. Clonal evolution mechanisms in NT5C2 mutant-relapsed acute lymphoblastic leukaemia. Nature 2018, 553, 511-514. [CrossRef] [PubMed]

31. Tzoneva, G.; Perez-Garcia, A.; Carpenter, Z.; Khiabanian, H.; Tosello, V.; Allegretta, M.; Paietta, E.; Racevskis, J.; Rowe, J.M.; Tallman, M.S.; et al. Activating mutations in the NT5C2 nucleotidase gene drive chemotherapy resistance in relapsed ALL. Nat. Med. 2013, 19, 368-371. [CrossRef] [PubMed]

32. Mitra, A.K.; Crews, K.R.; Pounds, S.; Cao, X.; Feldberg, T.; Ghodke, Y.; Gandhi, V.; Plunkett, W.; Dolan, M.E.; Hartford, C.; et al. Genetic variants in cytosolic $5^{\prime}$-nucleotidase II are associated with its expression and cytarabine sensitivity in HapMap cell lines and in patients with acute myeloid leukemia. J. Pharmacol. Exp. Ther. 2011, 339, 9-23. [CrossRef] [PubMed]

33. Cheong, H.S.; Koh, Y.; Ahn, K.S.; Lee, C.; Shin, H.D.; Yoon, S.S. NT5C3 polymorphisms and outcome of first induction chemotherapy in acute myeloid leukemia. Pharmacogenet. Genom. 2014, 24, 436-441. [CrossRef] [PubMed]

34. Edahiro, K.; Iimori, M.; Kobunai, T.; Morikawa-Ichinose, T.; Miura, D.; Kataoka, Y.; Niimi, S.; Wakasa, T.; Saeki, H.; Oki, E.; et al. Thymidine Kinase 1 Loss Confers Trifluridine Resistance without Affecting 5-Fluorouracil Metabolism and Cytotoxicity. Mol. Cancer Res. MCR 2018. [CrossRef] [PubMed]

35. Mekras, J.A.; Boothman, D.A.; Perez, L.M.; Greer, S. Use of 5-fluorodeoxycytidine and tetrahydrouridine to exploit high levels of deoxycytidylate deaminase in tumors to achieve DNA- and target-directed therapies. Cancer Res. 1984, 44, 2551-2560. [PubMed] 
36. Heinemann, V.; Plunkett, W. Modulation of deoxynucleotide metabolism by the deoxycytidylate deaminase inhibitor 3,4,5,6-tetrahydrodeoxyuridine. Biochem. Pharmacol. 1989, 38, 4115-4121. [CrossRef]

37. Klanova, M.; Lorkova, L.; Vit, O.; Maswabi, B.; Molinsky, J.; Pospisilova, J.; Vockova, P.; Mavis, C.; Lateckova, L.; Kulvait, V.; et al. Downregulation of deoxycytidine kinase in cytarabine-resistant mantle cell lymphoma cells confers cross-resistance to nucleoside analogs gemcitabine, fludarabine and cladribine, but not to other classes of anti-lymphoma agents. Mol. Cancer 2014, 13, 159. [CrossRef] [PubMed]

38. Lorkova, L.; Scigelova, M.; Arrey, T.N.; Vit, O.; Pospisilova, J.; Doktorova, E.; Klanova, M.; Alam, M.; Vockova, P.; Maswabi, B.; et al. Detailed Functional and Proteomic Characterization of Fludarabine Resistance in Mantle Cell Lymphoma Cells. PLoS ONE 2015, 10, e0135314. [CrossRef] [PubMed]

39. Geutjes, E.J.; Tian, S.; Roepman, P.; Bernards, R. Deoxycytidine kinase is overexpressed in poor outcome breast cancer and determines responsiveness to nucleoside analogs. Breast Cancer Res. Treat. 2012, 131, 809-818. [CrossRef] [PubMed]

40. Kurata, M.; Rathe, S.K.; Bailey, N.J.; Aumann, N.K.; Jones, J.M.; Veldhuijzen, G.W.; Moriarity, B.S.; Largaespada, D.A. Using genome-wide CRISPR library screening with library resistant DCK to find new sources of Ara-C drug resistance in AML. Sci. Rep. 2016, 6, 36199. [CrossRef] [PubMed]

41. Malani, D.; Murumagi, A.; Yadav, B.; Kontro, M.; Eldfors, S.; Kumar, A.; Karjalainen, R.; Majumder, M.M.; Ojamies, P.; Pemovska, T.; et al. Enhanced sensitivity to glucocorticoids in cytarabine-resistant AML. Leukemia 2017, 31, 1187-1195. [CrossRef] [PubMed]

42. Van den Heuvel-Eibrink, M.M.; Wiemer, E.A.; Kuijpers, M.; Pieters, R.; Sonneveld, P. Absence of mutations in the deoxycytidine kinase $(\mathrm{dCK})$ gene in patients with relapsed and/or refractory acute myeloid leukemia (AML). Leukemia 2001, 15, 855-856. [CrossRef] [PubMed]

43. Veuger, M.J.; Honders, M.W.; Landegent, J.E.; Willemze, R.; Barge, R.M. High incidence of alternatively spliced forms of deoxycytidine kinase in patients with resistant acute myeloid leukemia. Blood 2000, 96, 1517-1524. [PubMed]

44. Medina-Sanson, A.; Ramirez-Pacheco, A.; Moreno-Guerrero, S.S.; Dorantes-Acosta, E.M.; Sanchez-Preza, M.; Reyes-Lopez, A. Role of Genetic Polymorphisms of Deoxycytidine Kinase and Cytidine Deaminase to Predict Risk of Death in Children with Acute Myeloid Leukemia. BioMed Res. Int. 2015, 2015, 309491. [CrossRef] [PubMed]

45. Gabor, K.M.; Schermann, G.; Lautner-Csorba, O.; Rarosi, F.; Erdelyi, D.J.; Endreffy, E.; Berek, K.; Bartyik, K.; Bereczki, C.; Szalai, C.; et al. Impact of single nucleotide polymorphisms of cytarabine metabolic genes on drug toxicity in childhood acute lymphoblastic leukemia. Pediatr. Blood Cancer 2015, 62, 622-628. [CrossRef] [PubMed]

46. Spasokoukotskaja, T.; Sasvari-Szekely, M.; Keszler, G.; Albertioni, F.; Eriksson, S.; Staub, M. Treatment of normal and malignant cells with nucleoside analogues and etoposide enhances deoxycytidine kinase activity. Eur. J. Cancer 1999, 35, 1862-1867. [CrossRef]

47. Mehellou, Y.; Balzarini, J.; McGuigan, C. Aryloxy phosphoramidate triesters: A technology for delivering monophosphorylated nucleosides and sugars into cells. ChemMedChem 2009, 4, 1779-1791. [CrossRef] [PubMed]

48. Sheridan, C. FDA approvals usher in the post-interferon era in HCV. Nat. Biotechnol. 2014, 32, 3-5. [CrossRef] [PubMed]

49. Slusarczyk, M.; Lopez, M.H.; Balzarini, J.; Mason, M.; Jiang, W.G.; Blagden, S.; Thompson, E.; Ghazaly, E.; McGuigan, C. Application of ProTide technology to gemcitabine: A successful approach to overcome the key cancer resistance mechanisms leads to a new agent (NUC-1031) in clinical development. J. Med. Chem. 2014, 57, 1531-1542. [CrossRef] [PubMed]

50. Tobias, S.C.; Borch, R.F. Synthesis and biological evaluation of a cytarabine phosphoramidate prodrug. Mol. Pharm. 2004, 1, 112-116. [CrossRef] [PubMed]

51. Jordheim, L.P.; Cros, E.; Gouy, M.H.; Galmarini, C.M.; Peyrottes, S.; Mackey, J.; Perigaud, C.; Dumontet, C. Characterization of a gemcitabine-resistant murine leukemic cell line: Reversion of in vitro resistance by a mononucleotide prodrug. Clin. Cancer Res. 2004, 10, 5614-5621. [CrossRef] [PubMed]

52. Yamauchi, T.; Uzui, K.; Nishi, R.; Shigemi, H.; Ueda, T. Cytarabine-resistant leukemia cells are moderately sensitive to clofarabine in vitro. Anticancer Res. 2014, 34, 1657-1662. [PubMed] 
53. Yamauchi, T.; Uzui, K.; Nishi, R.; Shigemi, H.; Ueda, T. Reduced drug incorporation into DNA and antiapoptosis as the crucial mechanisms of resistance in a novel nelarabine-resistant cell line. BMC Cancer 2014, 14, 547. [CrossRef] [PubMed]

54. Zhu, C.; Johansson, M.; Permert, J.; Karlsson, A. Enhanced cytotoxicity of nucleoside analogs by overexpression of mitochondrial deoxyguanosine kinase in cancer cell lines. J. Biol. Chem. 1998, 273, 14707-14711. [CrossRef] [PubMed]

55. Meulendijks, D.; Henricks, L.M.; Sonke, G.S.; Deenen, M.J.; Froehlich, T.K.; Amstutz, U.; Largiader, C.R.; Jennings, B.A.; Marinaki, A.M.; Sanderson, J.D.; et al. Clinical relevance of DPYD variants c.1679T>G, c.1236G>A/HapB3, and c.1601G>A as predictors of severe fluoropyrimidine-associated toxicity: A systematic review and meta-analysis of individual patient data. Lancet Oncol. 2015, 16, 1639-1650. [CrossRef]

56. Del Re, M.; Restante, G.; Di Paolo, A.; Crucitta, S.; Rofi, E.; Danesi, R. Pharmacogenetics and Metabolism from Science to Implementation in Clinical Practice: The Example of Dihydropyrimidine Dehydrogenase. Curr. Pharm. Des. 2017, 23, 2028-2034. [PubMed]

57. Rivera, E.; Chang, J.C.; Semiglazov, V.; Burdaeva, O.; Kirby, M.G.; Spector, T. Eniluracil plus 5-fluorouracil and leucovorin: Treatment for metastatic breast cancer patients in whom capecitabine treatment rapidly failed. Clin. Breast Cancer 2014, 14, 26-30. [CrossRef] [PubMed]

58. Yen-Revollo, J.L.; Goldberg, R.M.; McLeod, H.L. Can inhibiting dihydropyrimidine dehydrogenase limit hand-foot syndrome caused by fluoropyrimidines? Clin. Cancer Res. 2008, 14, 8-13. [CrossRef] [PubMed]

59. Schmoll, H.J. Dihydropyrimidine dehydrogenase inhibition as a strategy for the oral administration of 5-fluorouracil: Utility in the treatment of advanced colorectal cancer. Anti-Cancer Drugs 2003, 14, 695-702. [CrossRef] [PubMed]

60. Li, Y.; Mizutani, Y.; Shiraishi, T.; Nakamura, T.; Mikami, K.; Takaha, N.; Okihara, K.; Kawauchi, A.; Sakai, T.; Miki, T. The significance of the expression of dihydropyrimidine dehydrogenase in prostate cancer. BJU Int. 2007, 99, 663-668. [CrossRef] [PubMed]

61. Yan, F.; Shen, N.; Pang, J.; Molina, J.R.; Yang, P.; Liu, S. The DNA Methyltransferase DNMT1 and Tyrosine-Protein Kinase KIT Cooperatively Promote Resistance to 5-Aza-2'-deoxycytidine (Decitabine) and Midostaurin (PKC412) in Lung Cancer Cells. J. Biol. Chem. 2015, 290, 18480-18494. [CrossRef] [PubMed]

62. Gnyszka, A.; Jastrzebski, Z.; Flis, S. DNA methyltransferase inhibitors and their emerging role in epigenetic therapy of cancer. Anticancer Res. 2013, 33, 2989-2996. [PubMed]

63. Ladner, R.D.; Lynch, F.J.; Groshen, S.; Xiong, Y.P.; Sherrod, A.; Caradonna, S.J.; Stoehlmacher, J.; Lenz, H.J. dUTP nucleotidohydrolase isoform expression in normal and neoplastic tissues: Association with survival and response to 5-fluorouracil in colorectal cancer. Cancer Res. 2000, 60, 3493-3503. [PubMed]

64. An, Q.; Robins, P.; Lindahl, T.; Barnes, D.E. 5-Fluorouracil incorporated into DNA is excised by the Smug1 DNA glycosylase to reduce drug cytotoxicity. Cancer Res. 2007, 67, 940-945. [CrossRef] [PubMed]

65. Hagenkort, A.; Paulin, C.B.J.; Desroses, M.; Sarno, A.; Wiita, E.; Mortusewicz, O.; Koolmeister, T.; Loseva, O.; Jemth, A.S.; Almlof, I.; et al. dUTPase inhibition augments replication defects of 5-Fluorouracil. Oncotarget 2017, 8, 23713-23726. [CrossRef] [PubMed]

66. Miyahara, S.; Miyakoshi, H.; Yokogawa, T.; Chong, K.T.; Taguchi, J.; Muto, T.; Endoh, K.; Yano, W.; Wakasa, T.; Ueno, H.; et al. Discovery of a novel class of potent human deoxyuridine triphosphatase inhibitors remarkably enhancing the antitumor activity of thymidylate synthase inhibitors. J. Med. Chem. 2012, 55, 2970-2980. [CrossRef] [PubMed]

67. Miyakoshi, H.; Miyahara, S.; Yokogawa, T.; Endoh, K.; Muto, T.; Yano, W.; Wakasa, T.; Ueno, H.; Chong, K.T.; Taguchi, J.; et al. 1,2,3-Triazole-containing uracil derivatives with excellent pharmacokinetics as a novel class of potent human deoxyuridine triphosphatase inhibitors. J. Med. Chem. 2012, 55, 6427-6437. [CrossRef] [PubMed]

68. Yano, W.; Yokogawa, T.; Wakasa, T.; Yamamura, K.; Fujioka, A.; Yoshisue, K.; Matsushima, E.; Miyahara, S.; Miyakoshi, H.; Taguchi, J.; et al. TAS-114, a First-in-Class Dual dUTPase/DPD Inhibitor, Demonstrates Potential to Improve Therapeutic Efficacy of Fluoropyrimidine-based Chemotherapy. Mol. Cancer Ther. 2018. [CrossRef] [PubMed]

69. Karim, H.; Hashemi, J.; Larsson, C.; Moshfegh, A.; Fotoohi, A.K.; Albertioni, F. The pattern of gene expression and gene dose profiles of 6-Mercaptopurine- and 6-Thioguanine-resistant human leukemia cells. Biochem. Biophys. Res. Commun. 2011, 411, 156-161. [CrossRef] [PubMed] 
70. Fotoohi, A.K.; Lindqvist, M.; Peterson, C.; Albertioni, F. Involvement of the concentrative nucleoside transporter 3 and equilibrative nucleoside transporter 2 in the resistance of T-lymphoblastic cell lines to thiopurines. Biochem. Biophys. Res. Commun. 2006, 343, 208-215. [CrossRef] [PubMed]

71. Adams, D.J.; Sandvold, M.L.; Myhren, F.; Jacobsen, T.F.; Giles, F.; Rizzieri, D.A. Anti proliferative activity of ELACY (CP-4055) in combination with cloretazine (VNP40101M), idarubicin, gemcitabine, irinotecan and topotecan in human leukemia and lymphoma cells. Leuk. Lymphoma 2008, 49, 786-797. [CrossRef] [PubMed]

72. Rizzieri, D.; Vey, N.; Thomas, X.; Huguet-Rigal, F.; Schlenk, R.F.; Krauter, J.; Kindler, T.; Gjertsen, B.T.; Blau, I.W.; Jacobsen, T.F.; et al. A phase II study of elacytarabine in combination with idarubicin and of human equilibrative nucleoside transporter 1 expression in patients with acute myeloid leukemia and persistent blasts after the first induction course. Leuk. Lymphoma 2014, 55, 2114-2119. [CrossRef] [PubMed]

73. Roboz, G.J.; Rosenblat, T.; Arellano, M.; Gobbi, M.; Altman, J.K.; Montesinos, P.; O'Connell, C.; Solomon, S.R.; Pigneux, A.; Vey, N.; et al. International randomized phase III study of elacytarabine versus investigator choice in patients with relapsed/refractory acute myeloid leukemia. J. Clin. Oncol. 2014, 32, 1919-1926. [CrossRef] [PubMed]

74. Clarke, M.L.; Mackey, J.R.; Baldwin, S.A.; Young, J.D.; Cass, C.E. The role of membrane transporters in cellular resistance to anticancer nucleoside drugs. Cancer Treat. Res. 2002, 112, 27-47. [PubMed]

75. Hubeek, I.; Peters, G.J.; Broekhuizen, R.; Zwaan, C.M.; Kaaijk, P.; van Wering, E.S.; Gibson, B.E.; Creutzig, U.; Janka-Schaub, G.E.; den Boer, M.L.; et al. In vitro sensitivity and cross-resistance to deoxynucleoside analogs in childhood acute leukemia. Haematologica 2006, 91, 17-23. [PubMed]

76. Damaraju, V.L.; Damaraju, S.; Young, J.D.; Baldwin, S.A.; Mackey, J.; Sawyer, M.B.; Cass, C.E. Nucleoside anticancer drugs: The role of nucleoside transporters in resistance to cancer chemotherapy. Oncogene 2003, 22, 7524-7536. [CrossRef] [PubMed]

77. Zhang, J.; Visser, F.; King, K.M.; Baldwin, S.A.; Young, J.D.; Cass, C.E. The role of nucleoside transporters in cancer chemotherapy with nucleoside drugs. Cancer Metastasis Rev. 2007, 26, 85-110. [CrossRef] [PubMed]

78. Espinoza, J.A.; Garcia, P.; Bizama, C.; Leal, J.L.; Riquelme, I.; Weber, H.; Macanas, P.; Aguayo, G.; Vinuela, E.; Roa, J.C.; et al. Low expression of equilibrative nucleoside transporter 1 is associated with poor prognosis in chemotherapy-naive pT2 gallbladder adenocarcinoma patients. Histopathology 2016, 68, 722-728. [CrossRef] [PubMed]

79. Greenhalf, W.; Ghaneh, P.; Neoptolemos, J.P.; Palmer, D.H.; Cox, T.F.; Lamb, R.F.; Garner, E.; Campbell, F.; Mackey, J.R.; Costello, E.; et al. Pancreatic cancer hENT1 expression and survival from gemcitabine in patients from the ESPAC-3 trial. J. Natl. Cancer Inst. 2014, 106, djt347. [CrossRef] [PubMed]

80. Mohelnikova-Duchonova, B.; Brynychova, V.; Hlavac, V.; Kocik, M.; Oliverius, M.; Hlavsa, J.; Honsova, E.; Mazanec, J.; Kala, Z.; Melichar, B.; et al. The association between the expression of solute carrier transporters and the prognosis of pancreatic cancer. Cancer Chemother. Pharmacol. 2013, 72, 669-682. [CrossRef] [PubMed]

81. Suenaga, M.; Schirripa, M.; Cao, S.; Zhang, W.; Yang, D.; Dadduzio, V.; Salvatore, L.; Borelli, B.; Pietrantonio, F.; Ning, Y.; et al. Potential role of polymorphisms in the transporter genes ENT1 and MATE1/OCT2 in predicting TAS-102 efficacy and toxicity in patients with refractory metastatic colorectal cancer. Eur. J. Cancer 2017, 86, 197-206. [CrossRef] [PubMed]

82. Lemstrova, R.; Soucek, P.; Melichar, B.; Mohelnikova-Duchonova, B. Role of solute carrier transporters in pancreatic cancer: A review. Pharmacogenomics 2014, 15, 1133-1145. [CrossRef] [PubMed]

83. Muller, P.; Asher, N.; Heled, M.; Cohen, S.B.; Risch, A.; Rund, D. Polymorphisms in transporter and phase II metabolism genes as potential modifiers of the predisposition to and treatment outcome of de novo acute myeloid leukemia in Israeli ethnic groups. Leuk. Res. 2008, 32, 919-929. [CrossRef] [PubMed]

84. Galmarini, C.M.; Thomas, X.; Calvo, F.; Rousselot, P.; Rabilloud, M.; El Jaffari, A.; Cros, E.; Dumontet, C. In vivo mechanisms of resistance to cytarabine in acute myeloid leukaemia. Br. J. Haematol. 2002, 117, 860-868. [CrossRef] [PubMed]

85. Song, J.H.; Cho, K.M.; Kim, H.J.; Kim, Y.K.; Kim, N.Y.; Kim, H.J.; Lee, T.H.; Hwang, S.Y.; Kim, T.S. Concentrative nucleoside transporter 3 as a prognostic indicator for favorable outcome of $\mathrm{t}(8 ; 21)$-positive acute myeloid leukemia patients after cytarabine-based chemotherapy. Oncol. Rep. 2015, 34, 488-494. [CrossRef] [PubMed] 
86. Candelaria, M.; Corrales-Alfaro, C.; Gutierrez-Hernandez, O.; Diaz-Chavez, J.; Labardini-Mendez, J.; Vidal-Millan, S.; Herrera, L.A. Expression Levels of Human Equilibrative Nucleoside Transporter 1 and Deoxycytidine Kinase Enzyme as Prognostic Factors in Patients with Acute Myeloid Leukemia Treated with Cytarabine. Chemotherapy 2016, 61, 313-318. [CrossRef] [PubMed]

87. Wan, H.; Zhu, J.; Chen, F.; Xiao, F.; Huang, H.; Han, X.; Zhong, L.; Zhong, H.; Xu, L.; Ni, B.; et al. SLC29A1 single nucleotide polymorphisms as independent prognostic predictors for survival of patients with acute myeloid leukemia: An in vitro study. J. Exp. Clin. Cancer Res. 2014, 33, 90. [CrossRef] [PubMed]

88. Wright, A.M.; Gati, W.P.; Paterson, A.R. Enhancement of retention and cytotoxicity of 2-chlorodeoxyadenosine in cultured human leukemic lymphoblasts by nitrobenzylthioinosine, an inhibitor of equilibrative nucleoside transport. Leukemia 2000, 14, 52-60. [CrossRef] [PubMed]

89. Pieters, R.; Huismans, D.R.; Loonen, A.H.; Peters, G.J.; Hahlen, K.; van der Does-van den Berg, A.; van Wering, E.R.; Veerman, A.J. Hypoxanthine-guanine phosphoribosyl-transferase in childhood leukemia: Relation with immunophenotype, in vitro drug resistance and clinical prognosis. Int. J. Cancer 1992, 51, 213-217. [CrossRef] [PubMed]

90. Zimm, S.; Reaman, G.; Murphy, R.F.; Poplack, D.G. Biochemical parameters of mercaptopurine activity in patients with acute lymphoblastic leukemia. Cancer Res. 1986, 46, 1495-1498. [PubMed]

91. Brackett, J.; Schafer, E.S.; Leung, D.H.; Bernhardt, M.B. Use of allopurinol in children with acute lymphoblastic leukemia to reduce skewed thiopurine metabolism. Pediatr. Blood Cancer 2014, 61, 1114-1117. [CrossRef] [PubMed]

92. Seinen, M.L.; van Asseldonk, D.P.; de Boer, N.K.; Losekoot, N.; Smid, K.; Mulder, C.J.; Bouma, G.; Peters, G.J.; van Bodegraven, A.A. The effect of allopurinol and low-dose thiopurine combination therapy on the activity of three pivotal thiopurine metabolizing enzymes: Results from a prospective pharmacological study. J. Crohn's Colitis 2013, 7, 812-819. [CrossRef] [PubMed]

93. Roberts, R.L.; Gearry, R.B.; Barclay, M.L.; Kennedy, M.A. IMPDH1 promoter mutations in a patient exhibiting azathioprine resistance. Pharmacogenom. J. 2007, 7, 312-317. [CrossRef] [PubMed]

94. Adam de Beaumais, T.; Fakhoury, M.; Medard, Y.; Azougagh, S.; Zhang, D.; Yakouben, K.; Jacqz-Aigrain, E. Determinants of mercaptopurine toxicity in paediatric acute lymphoblastic leukemia maintenance therapy. Br. J. Clin. Pharmacol. 2011, 71, 575-584. [CrossRef] [PubMed]

95. Gerbek, T.; Ebbesen, M.; Nersting, J.; Frandsen, T.L.; Appell, M.L.; Schmiegelow, K. Role of TPMT and ITPA variants in mercaptopurine disposition. Cancer Chemother. Pharmacol. 2018, 81, 579-586. [CrossRef] [PubMed]

96. Franca, R.; Rebora, P.; Bertorello, N.; Fagioli, F.; Conter, V.; Biondi, A.; Colombini, A.; Micalizzi, C.; Zecca, M.; Parasole, R.; et al. Pharmacogenetics and induction/consolidation therapy toxicities in acute lymphoblastic leukemia patients treated with AIEOP-BFM ALL 2000 protocol. Pharmacogenom. J. 2017, 17, 4-10. [CrossRef] [PubMed]

97. Matimba, A.; Li, F.; Livshits, A.; Cartwright, C.S.; Scully, S.; Fridley, B.L.; Jenkins, G.; Batzler, A.; Wang, L.; Weinshilboum, R.; et al. Thiopurine pharmacogenomics: Association of SNPs with clinical response and functional validation of candidate genes. Pharmacogenomics 2014, 15, 433-447. [CrossRef] [PubMed]

98. Carter, M.; Jemth, A.S.; Hagenkort, A.; Page, B.D.; Gustafsson, R.; Griese, J.J.; Gad, H.; Valerie, N.C.; Desroses, M.; Bostrom, J.; et al. Crystal structure, biochemical and cellular activities demonstrate separate functions of MTH1 and MTH2. Nat. Commun. 2015, 6, 7871. [CrossRef] [PubMed]

99. Braunagel, D.; Schaich, M.; Kramer, M.; Dransfeld, C.L.; Ehninger, G.; Mahlknecht, U. The T_T genotype within the NME1 promoter single nucleotide polymorphism-835 C/T is associated with an increased risk of cytarabine induced neurotoxicity in patients with acute myeloid leukemia. Leuk. Lymphoma 2012, 53, 952-957. [CrossRef] [PubMed]

100. Zhu, K.W.; Chen, P.; Zhang, D.Y.; Yan, H.; Liu, H.; Cen, L.N.; Liu, Y.L.; Cao, S.; Zhou, G.; Zeng, H.; et al. Association of genetic polymorphisms in genes involved in Ara-C and dNTP metabolism pathway with chemosensitivity and prognosis of adult acute myeloid leukemia (AML). J. Transl. Med. 2018, 16, 90. [CrossRef] [PubMed]

101. Meier, C. Nucleoside diphosphate and triphosphate prodrugs-An unsolvable task? Antivir. Chem. Chemother. 2017, 25, 69-82. [CrossRef] [PubMed]

102. Metzeler, K.H.; Walker, A.; Geyer, S.; Garzon, R.; Klisovic, R.B.; Bloomfield, C.D.; Blum, W.; Marcucci, G. DNMT3A mutations and response to the hypomethylating agent decitabine in acute myeloid leukemia. Leukemia 2012, 26, 1006. [CrossRef] [PubMed] 
103. Goan, Y.G.; Zhou, B.; Hu, E.; Mi, S.; Yen, Y. Overexpression of ribonucleotide reductase as a mechanism of resistance to 2,2-difluorodeoxycytidine in the human KB cancer cell line. Cancer Res. 1999, 59, 4204-4207. [PubMed]

104. Davidson, J.D.; Ma, L.; Flagella, M.; Geeganage, S.; Gelbert, L.M.; Slapak, C.A. An increase in the expression of ribonucleotide reductase large subunit 1 is associated with gemcitabine resistance in non-small cell lung cancer cell lines. Cancer Res. 2004, 64, 3761-3766. [CrossRef] [PubMed]

105. Nakahira, S.; Nakamori, S.; Tsujie, M.; Takahashi, Y.; Okami, J.; Yoshioka, S.; Yamasaki, M.; Marubashi, S.; Takemasa, I.; Miyamoto, A.; et al. Involvement of ribonucleotide reductase M1 subunit overexpression in gemcitabine resistance of human pancreatic cancer. Int. J. Cancer 2007, 120, 1355-1363. [CrossRef] [PubMed]

106. Jordheim, L.P.; Guittet, O.; Lepoivre, M.; Galmarini, C.M.; Dumontet, C. Increased expression of the large subunit of ribonucleotide reductase is involved in resistance to gemcitabine in human mammary adenocarcinoma cells. Mol. Cancer Ther. 2005, 4, 1268-1276. [CrossRef] [PubMed]

107. Bergman, A.M.; Eijk, P.P.; Ruiz van Haperen, V.W.; Smid, K.; Veerman, G.; Hubeek, I.; van den Ijssel, P.; Ylstra, B.; Peters, G.J. In vivo induction of resistance to gemcitabine results in increased expression of ribonucleotide reductase subunit M1 as the major determinant. Cancer Res. 2005, 65, 9510-9516. [CrossRef] [PubMed]

108. Itoi, T.; Sofuni, A.; Fukushima, N.; Itokawa, F.; Tsuchiya, T.; Kurihara, T.; Moriyasu, F.; Tsuchida, A.; Kasuya, K. Ribonucleotide reductase subunit M2 mRNA expression in pretreatment biopsies obtained from unresectable pancreatic carcinomas. J. Gastroenterol. 2007, 42, 389-394. [CrossRef] [PubMed]

109. Kim, M.; Ku, J.H.; Kwak, C.; Kim, H.H.; Lee, E.; Keam, B.; Kim, T.M.; Heo, D.S.; Lee, S.H.; Moon, K.C. Predictive and Prognostic Value of Ribonucleotide Reductase Regulatory Subunit M1 and Excision Repair Cross-Complementation Group 1 in Advanced Urothelial Carcinoma (UC) Treated with First-Line Gemcitabine Plus Platinum Combination Chemotherapy. PLoS ONE 2015, 10, e0133371. [CrossRef] [PubMed]

110. Bepler, G.; Kusmartseva, I.; Sharma, S.; Gautam, A.; Cantor, A.; Sharma, A.; Simon, G. RRM1 modulated in vitro and in vivo efficacy of gemcitabine and platinum in non-small-cell lung cancer. J. Clin. Oncol. 2006, 24, 4731-4737. [CrossRef] [PubMed]

111. Rosell, R.; Danenberg, K.D.; Alberola, V.; Bepler, G.; Sanchez, J.J.; Camps, C.; Provencio, M.; Isla, D.; Taron, M.; Diz, P.; et al. Ribonucleotide reductase messenger RNA expression and survival in gemcitabine/cisplatin-treated advanced non-small cell lung cancer patients. Clin. Cancer Res. 2004, 10, 1318-1325. [CrossRef] [PubMed]

112. Nakamura, J.; Kohya, N.; Kai, K.; Ohtaka, K.; Hashiguchi, K.; Hiraki, M.; Kitajima, Y.; Tokunaga, O.; Noshiro, H.; Miyazaki, K. Ribonucleotide reductase subunit M1 assessed by quantitative double-fluorescence immunohistochemistry predicts the efficacy of gemcitabine in biliary tract carcinoma. Int. J. Oncol. 2010, 37, 845-852. [PubMed]

113. Ferrandina, G.; Mey, V.; Nannizzi, S.; Ricciardi, S.; Petrillo, M.; Ferlini, C.; Danesi, R.; Scambia, G.; Del Tacca, M. Expression of nucleoside transporters, deoxycitidine kinase, ribonucleotide reductase regulatory subunits, and gemcitabine catabolic enzymes in primary ovarian cancer. Cancer Chemother. Pharmacol. 2010, 65, 679-686. [CrossRef] [PubMed]

114. Boukovinas, I.; Papadaki, C.; Mendez, P.; Taron, M.; Mavroudis, D.; Koutsopoulos, A.; Sanchez-Ronco, M.; Sanchez, J.J.; Trypaki, M.; Staphopoulos, E.; et al. Tumor BRCA1, RRM1 and RRM2 mRNA expression levels and clinical response to first-line gemcitabine plus docetaxel in non-small-cell lung cancer patients. PLOS ONE 2008, 3, e3695. [CrossRef] [PubMed]

115. Kim, S.O.; Jeong, J.Y.; Kim, M.R.; Cho, H.J.; Ju, J.Y.; Kwon, Y.S.; Oh, I.J.; Kim, K.S.; Kim, Y.I.; Lim, S.C.; et al. Efficacy of gemcitabine in patients with non-small cell lung cancer according to promoter polymorphisms of the ribonucleotide reductase M1 gene. Clin. Cancer Res. 2008, 14, 3083-3088. [CrossRef] [PubMed]

116. Gotanda, K.; Hirota, T.; Matsumoto, N.; Ieiri, I. MicroRNA-433 negatively regulates the expression of thymidylate synthase (TYMS) responsible for 5-fluorouracil sensitivity in HeLa cells. BMC Cancer 2013, 13, 369. [CrossRef] [PubMed]

117. Herold, N.; Rudd, S.G.; Ljungblad, L.; Sanjiv, K.; Myrberg, I.H.; Paulin, C.B.; Heshmati, Y.; Hagenkort, A.; Kutzner, J.; Page, B.D.; et al. Targeting SAMHD1 with the Vpx protein to improve cytarabine therapy for hematological malignancies. Nat. Med. 2017, 23, 256-263. [CrossRef] [PubMed] 
118. Herold, N.; Rudd, S.G.; Sanjiv, K.; Kutzner, J.; Myrberg, I.H.; Paulin, C.B.J.; Olsen, T.K.; Helleday, T.; Henter, J.I.; Schaller, T. With me or against me: Tumor suppressor and drug resistance activities of SAMHD1. Exp. Hematol. 2017, 52, 32-39. [CrossRef] [PubMed]

119. Coulthard, S.A.; Matheson, E.C.; Hall, A.G.; Hogarth, L.A. The clinical impact of thiopurine methyltransferase polymorphisms on thiopurine treatment. Nucleosides Nucleotides Nucleic Acids 2004, 23, 1385-1391. [CrossRef] [PubMed]

120. Blaker, P.A.; Arenas-Hernandez, M.; Smith, M.A.; Shobowale-Bakre, E.A.; Fairbanks, L.; Irving, P.M.; Sanderson, J.D.; Marinaki, A.M. Mechanism of allopurinol induced TPMT inhibition. Biochem. Pharmacol. 2013, 86, 539-547. [CrossRef] [PubMed]

121. Che, J.; Pan, L.; Yang, X.; Liu, Z.; Huang, L.; Wen, C.; Lin, A.; Liu, H. Thymidine phosphorylase expression and prognosis in colorectal cancer treated with 5-fluorouracil-based chemotherapy: A meta-analysis. Mol. Clin. Oncol. 2017, 7, 943-952. [CrossRef] [PubMed]

122. Cleary, J.M.; Rosen, L.S.; Yoshida, K.; Rasco, D.; Shapiro, G.I.; Sun, W. A phase 1 study of the pharmacokinetics of nucleoside analog trifluridine and thymidine phosphorylase inhibitor tipiracil (components of TAS-102) vs trifluridine alone. Investig. New Drugs 2017, 35, 189-197. [CrossRef] [PubMed]

123. Marcus, L.; Lemery, S.J.; Khasar, S.; Wearne, E.; Helms, W.S.; Yuan, W.; He, K.; Cao, X.; Yu, J.; Zhao, H.; et al. FDA Approval Summary: TAS-102. Clin. Cancer Res. 2017, 23, 2924-2927. [CrossRef] [PubMed]

124. Nadella, P.; Shapiro, C.; Otterson, G.A.; Hauger, M.; Erdal, S.; Kraut, E.; Clinton, S.; Shah, M.; Stanek, M.; Monk, P.; et al. Pharmacobiologically based scheduling of capecitabine and docetaxel results in antitumor activity in resistant human malignancies. J. Clin. Oncol. 2002, 20, 2616-2623. [CrossRef] [PubMed]

125. Matsuoka, K.; Nakagawa, F.; Kobunai, T.; Takechi, T. Trifluridine/tipiracil overcomes the resistance of human gastric 5-fluorouracil-refractory cells with high thymidylate synthase expression. Oncotarget 2018, 9, 13438-13450. [CrossRef] [PubMed]

126. Murakami, Y.; Kazuno, H.; Emura, T.; Tsujimoto, H.; Suzuki, N.; Fukushima, M. Different mechanisms of acquired resistance to fluorinated pyrimidines in human colorectal cancer cells. Int. J. Oncol. 2000, 17, 277-283. [CrossRef] [PubMed]

127. Ahn, J.Y.; Lee, J.S.; Min, H.Y.; Lee, H.Y. Acquired resistance to 5-fluorouracil via HSP90/Src-mediated increase in thymidylate synthase expression in colon cancer. Oncotarget 2015, 6, 32622-32633. [CrossRef] [PubMed]

128. Fazzone, W.; Wilson, P.M.; Labonte, M.J.; Lenz, H.J.; Ladner, R.D. Histone deacetylase inhibitors suppress thymidylate synthase gene expression and synergize with the fluoropyrimidines in colon cancer cells. Int. J. Cancer 2009, 125, 463-473. [CrossRef] [PubMed]

129. Li, T.; Gao, F.; Zhang, X.P. miR-203 enhances chemosensitivity to 5-fluorouracil by targeting thymidylate synthase in colorectal cancer. Oncol. Rep. 2015, 33, 607-614. [CrossRef] [PubMed]

130. Calascibetta, A.; Martorana, A.; Cabibi, D.; Aragona, F.; Sanguedolce, R. Relationship between thymidylate synthase and p53 and response to FEC versus taxane adjuvant chemotherapy for breast carcinoma. J. Chemother. 2011, 23, 354-357. [CrossRef] [PubMed]

131. Becker, M.A.; Kim, M.; Husain, K.; Kang, T. Regulation of purine nucleotide synthesis in human B lymphoblasts with both hypoxanthine-guanine phosphoribosyltransferase deficiency and phosphoribosylpyrophosphate synthetase superactivity. J. Biol. Chem. 1992, 267, 4317-4321. [PubMed]

132. Humeniuk, R.; Menon, L.G.; Mishra, P.J.; Gorlick, R.; Sowers, R.; Rode, W.; Pizzorno, G.; Cheng, Y.C.; Kemeny, N.; Bertino, J.R.; et al. Decreased levels of UMP kinase as a mechanism of fluoropyrimidine resistance. Mol. Cancer Ther. 2009, 8, 1037-1044. [CrossRef] [PubMed]

133. Woo, H.I.; Kim, K.K.; Choi, H.; Kim, S.; Jang, K.T.; Yi, J.H.; Park, Y.S.; Park, J.O.; Lee, S.Y. Effect of genetic polymorphisms on therapeutic response and clinical outcomes in pancreatic cancer patients treated with gemcitabine. Pharmacogenomics 2012, 13, 1023-1035. [CrossRef] [PubMed]

134. Ryu, J.S.; Shin, E.S.; Nam, H.S.; Yi, H.G.; Cho, J.H.; Kim, C.S.; Kim, H.J.; Lee, J.E. Differential effect of polymorphisms of CMPK1 and RRM1 on survival in advanced non-small cell lung cancer patients treated with gemcitabine or taxane/cisplatinum. J. Thorac. Oncol. 2011, 6, 1320-1329. [CrossRef] [PubMed]

135. Tsutani, Y.; Yoshida, K.; Sanada, Y.; Wada, Y.; Konishi, K.; Fukushima, M.; Okada, M. Decreased orotate phosphoribosyltransferase activity produces 5 -fluorouracil resistance in a human gastric cancer cell line. Oncol. Rep. 2008, 20, 1545-1551. [PubMed] 
136. Im, Y.S.; Shin, H.K.; Kim, H.R.; Jeong, S.H.; Kim, S.R.; Kim, Y.M.; Lee, D.H.; Jeon, S.H.; Lee, H.W.; Choi, J.K. Enhanced cytotoxicity of 5-FU by bFGF through up-regulation of uridine phosphorylase 1. Mol. Cells 2009, 28, 119-124. [CrossRef] [PubMed]

137. Renck, D.; Machado, P.; Souto, A.A.; Rosado, L.A.; Erig, T.; Campos, M.M.; Farias, C.B.; Roesler, R.; Timmers, L.F.; de Souza, O.N.; et al. Design of novel potent inhibitors of human uridine phosphorylase-1: Synthesis, inhibition studies, thermodynamics, and in vitro influence on 5-fluorouracil cytotoxicity. J. Med. Chem. 2013, 56, 8892-8902. [CrossRef] [PubMed]

138. Cividini, F.; Pesi, R.; Chaloin, L.; Allegrini, S.; Camici, M.; Cros-Perrial, E.; Dumontet, C.; Jordheim, L.P.; Tozzi, M.G. The purine analog fludarabine acts as a cytosolic $5^{\prime}$-nucleotidase II inhibitor. Biochem. Pharmacol. 2015, 94, 63-68. [CrossRef] [PubMed]

139. Harrington, C.; Perrino, F.W. The effects of cytosine arabinoside on RNA-primed DNA synthesis by DNA polymerase alpha-primase. J. Biol. Chem. 1995, 270, 26664-26669. [CrossRef] [PubMed]

140. Mikita, T.; Beardsley, G.P. Functional consequences of the arabinosylcytosine structural lesion in DNA. Biochemistry 1988, 27, 4698-4705. [CrossRef] [PubMed]

141. Perrino, F.W.; Mekosh, H.L. Incorporation of cytosine arabinoside monophosphate into DNA at internucleotide linkages by human DNA polymerase alpha. J. Biol. Chem. 1992, 267, 23043-23051. [PubMed]

142. Tsuda, M.; Terada, K.; Ooka, M.; Kobayashi, K.; Sasanuma, H.; Fujisawa, R.; Tsurimoto, T.; Yamamoto, J.; Iwai, S.; Kadoda, K.; et al. The dominant role of proofreading exonuclease activity of replicative polymerase epsilon in cellular tolerance to cytarabine (Ara-C). Oncotarget 2017, 8, 33457-33474. [CrossRef] [PubMed]

143. Mesa, R.A.; Loegering, D.; Powell, H.L.; Flatten, K.; Arlander, S.J.; Dai, N.T.; Heldebrant, M.P.; Vroman, B.T.; Smith, B.D.; Karp, J.E.; et al. Heat shock protein 90 inhibition sensitizes acute myelogenous leukemia cells to cytarabine. Blood 2005, 106, 318-327. [CrossRef] [PubMed]

144. Dijkwel, P.A.; Wanka, F. Enhanced release of nascent single strands from DNA synthesized in the presence of arabinosylcytosine. Biochim. Biophys. Acta 1978, 520, 461-471. [CrossRef]

145. Graham, F.L.; Whitmore, G.F. Studies in mouse L-cells on the incorporation of 1-beta-D-arabinofuranosylcytosine into DNA and on inhibition of DNA polymerase by 1-beta-D-arabinofuranosylcytosine 5'-triphosphate. Cancer Res. 1970, 30, 2636-2644. [PubMed]

146. Ross, D.D.; Chen, S.R.; Cuddy, D.P. Effects of 1-beta-D-arabinofuranosylcytosine on DNA replication intermediates monitored by $\mathrm{pH}$-step alkaline elution. Cancer Res. 1990, 50, 2658-2666. [PubMed]

147. Ross, D.D.; Cuddy, D.P.; Cohen, N.; Hensley, D.R. Mechanistic implications of alterations in HL-60 cell nascent DNA after exposure to 1-beta-D-arabinofuranosylcytosine. Cancer Chemother. Pharmacol. 1992, 31, 61-70. [CrossRef] [PubMed]

148. Huang, P.; Chubb, S.; Plunkett, W. Termination of DNA synthesis by 9-beta-D-arabinofuranosyl-2-fluoroadenine. A mechanism for cytotoxicity. J. Biol. Chem. 1990, 265, 16617-16625. [PubMed]

149. Xie, C.; Plunkett, W. Metabolism and actions of 2-chloro-9-(2-deoxy-2-fluoro-beta-D-arabinofuranosyl)-adenine in human lymphoblastoid cells. Cancer Res. 1995, 55, 2847-2852. [PubMed]

150. Huang, P.; Chubb, S.; Hertel, L.W.; Grindey, G.B.; Plunkett, W. Action of 2' 2' 2 '-difluorodeoxycytidine on DNA synthesis. Cancer Res. 1991, 51, 6110-6117. [PubMed]

151. Plunkett, W.; Huang, P.; Gandhi, V. Preclinical characteristics of gemcitabine. Anti-Cancer Drugs 1995, 6 (Suppl. S6), 7-13. [CrossRef] [PubMed]

152. Azuma, A.; Hanaoka, K.; Kurihara, A.; Kobayashi, T.; Miyauchi, S.; Kamo, N.; Tanaka, M.; Sasaki, T.; Matsuda, A. Nucleosides and nucleotides. 141. Chemical stability of a new antitumor nucleoside, 2'-C-cyano-2'-deoxy-1-beta-D-arabino-pentofuranosylcytosine in alkaline medium: Formation of 2'-C-cyano-2'-deoxy-1-beta-D-ribo-pentofuranosylcytosine and its antitumor activity. J. Med. Chem. 1995, 38, 3391-3397. [PubMed]

153. Azuma, A.; Huang, P.; Matsuda, A.; Plunkett, W. 2'-C-cyano-2'-deoxy-1-beta-D-arabino-pentofuranosylcytosine: A novel anticancer nucleoside analog that causes both DNA strand breaks and G(2) arrest. Mol. Pharmacol. 2001, 59, 725-731. [CrossRef] [PubMed]

154. Cuffari, C.; Li, D.Y.; Mahoney, J.; Barnes, Y.; Bayless, T.M. Peripheral blood mononuclear cell DNA 6-thioguanine metabolite levels correlate with decreased interferon-gamma production in patients with Crohn's disease on AZA therapy. Dig. Dis. Sci. 2004, 49, 133-137. [CrossRef] [PubMed] 
155. Ling, Y.H.; Nelson, J.A.; Cheng, Y.C.; Anderson, R.S.; Beattie, K.L. 2'-Deoxy-6-thioguanosine 5'-triphosphate as a substrate for purified human DNA polymerases and calf thymus terminal deoxynucleotidyltransferase in vitro. Mol. Pharmacol. 1991, 40, 508-514. [PubMed]

156. Nelson, J.A.; Carpenter, J.W.; Rose, L.M.; Adamson, D.J. Mechanisms of action of 6-thioguanine, 6-mercaptopurine, and 8-azaguanine. Cancer Res. 1975, 35, 2872-2878. [PubMed]

157. Warren, D.J.; Andersen, A.; Slordal, L. Quantitation of 6-thioguanine residues in peripheral blood leukocyte DNA obtained from patients receiving 6-mercaptopurine-based maintenance therapy. Cancer Res. 1995, 55, 1670-1674. [PubMed]

158. Karran, P.; Attard, N. Thiopurines in current medical practice: Molecular mechanisms and contributions to therapy-related cancer. Nat. Rev. Cancer 2008, 8, 24-36. [CrossRef] [PubMed]

159. Yoshida, S.; Yamada, M.; Masaki, S.; Saneyoshi, M. Utilization of 2'-deoxy-6-thioguanosine 5'-triphosphate in DNA synthesis in vitro by DNA polymerase alpha from calf thymus. Cancer Res. 1979, 39, 3955-3958. [PubMed]

160. Aquilina, G.; Giammarioli, A.M.; Zijno, A.; Di Muccio, A.; Dogliotti, E.; Bignami, M. Tolerance to O6-methylguanine and 6-thioguanine cytotoxic effects: A cross-resistant phenotype in N-methylnitrosourea-resistant Chinese hamster ovary cells. Cancer Res. 1990, 50, 4248-4253. [PubMed]

161. Swann, P.F.; Waters, T.R.; Moulton, D.C.; Xu, Y.Z.; Zheng, Q.; Edwards, M.; Mace, R. Role of postreplicative DNA mismatch repair in the cytotoxic action of thioguanine. Science 1996, 273, 1109-1111. [CrossRef] [PubMed]

162. Karran, P.; Bignami, M. DNA damage tolerance, mismatch repair and genome instability. BioEssays 1994, 16, 833-839. [CrossRef] [PubMed]

163. Stojic, L.; Mojas, N.; Cejka, P.; Di Pietro, M.; Ferrari, S.; Marra, G.; Jiricny, J. Mismatch repair-dependent G2 checkpoint induced by low doses of SN1 type methylating agents requires the ATR kinase. Genes Dev. 2004, 18, 1331-1344. [CrossRef] [PubMed]

164. Yan, T.; Berry, S.E.; Desai, A.B.; Kinsella, T.J. DNA mismatch repair (MMR) mediates 6-thioguanine genotoxicity by introducing single-strand breaks to signal a G2-M arrest in MMR-proficient RKO cells. Clin. Cancer Res. 2003, 9, 2327-2334. [PubMed]

165. Vernole, P.; Pepponi, R.; D'Atri, S. Role of mismatch repair in the induction of chromosomal aberrations and sister chromatid exchanges in cells treated with different chemotherapeutic agents. Cancer Chemother. Pharmacol. 2003, 52, 185-192. [PubMed]

166. Matheson, E.C.; Hall, A.G. Assessment of mismatch repair function in leukaemic cell lines and blasts from children with acute lymphoblastic leukaemia. Carcinogenesis 2003, 24, 31-38. [CrossRef] [PubMed]

167. Morimoto, H.; Tsukada, J.; Kominato, Y.; Tanaka, Y. Reduced expression of human mismatch repair genes in adult T-cell leukemia. Am. J. Hematol. 2005, 78, 100-107. [CrossRef] [PubMed]

168. You, C.; Dai, X.; Yuan, B.; Wang, Y. Effects of 6-thioguanine and S6-methylthioguanine on transcription in vitro and in human cells. J. Biol. Chem. 2012, 287, 40915-40923. [CrossRef] [PubMed]

169. Tiede, I.; Fritz, G.; Strand, S.; Poppe, D.; Dvorsky, R.; Strand, D.; Lehr, H.A.; Wirtz, S.; Becker, C.; Atreya, R.; et al. CD28-dependent Rac1 activation is the molecular target of azathioprine in primary human CD4+ T lymphocytes. J. Clin. Investig. 2003, 111, 1133-1145. [CrossRef] [PubMed]

170. Bouchard, J.; Momparler, R.L. Incorporation of 5-Aza-2'-deoxycytidine-5'-triphosphate into DNA. Interactions with mammalian DNA polymerase alpha and DNA methylase. Mol. Pharmacol. 1983, 24, 109-114. [PubMed]

171. Chen, L.; MacMillan, A.M.; Chang, W.; Ezaz-Nikpay, K.; Lane, W.S.; Verdine, G.L. Direct identification of the active-site nucleophile in a DNA (cytosine-5)-methyltransferase. Biochemistry 1991, 30, 11018-11025. [CrossRef] [PubMed]

172. Santi, D.V.; Norment, A.; Garrett, C.E. Covalent bond formation between a DNA-cytosine methyltransferase and DNA containing 5-azacytosine. Proc. Natl. Acad. Sci. USA 1984, 81, 6993-6997. [CrossRef] [PubMed]

173. Stresemann, C.; Lyko, F. Modes of action of the DNA methyltransferase inhibitors azacytidine and decitabine. Int. J. Cancer 2008, 123, 8-13. [CrossRef] [PubMed]

174. Yan, P.; Frankhouser, D.; Murphy, M.; Tam, H.H.; Rodriguez, B.; Curfman, J.; Trimarchi, M.; Geyer, S.; $\mathrm{Wu}$, Y.Z.; Whitman, S.P.; et al. Genome-wide methylation profiling in decitabine-treated patients with acute myeloid leukemia. Blood 2012, 120, 2466-2474. [CrossRef] [PubMed] 
175. Orta, M.L.; Calderon-Montano, J.M.; Dominguez, I.; Pastor, N.; Burgos-Moron, E.; Lopez-Lazaro, M.; Cortes, F.; Mateos, S.; Helleday, T. 5-Aza-2'-deoxycytidine causes replication lesions that require Fanconi anemia-dependent homologous recombination for repair. Nucleic Acids Res. 2013, 41, 5827-5836. [CrossRef] [PubMed]

176. Palii, S.S.; Van Emburgh, B.O.; Sankpal, U.T.; Brown, K.D.; Robertson, K.D. DNA methylation inhibitor 5-Aza-2'-deoxycytidine induces reversible genome-wide DNA damage that is distinctly influenced by DNA methyltransferases 1 and 3B. Mol. Cell. Biol. 2008, 28, 752-771. [CrossRef] [PubMed]

177. Heinemann, V.; Xu, Y.Z.; Chubb, S.; Sen, A.; Hertel, L.W.; Grindey, G.B.; Plunkett, W. Inhibition of ribonucleotide reduction in CCRF-CEM cells by $2^{\prime}, 2^{\prime}$-difluorodeoxycytidine. Mol. Pharmacol. 1990, 38, 567-572. [PubMed]

178. Wang, J.; Lohman, G.J.; Stubbe, J. Enhanced subunit interactions with gemcitabine-5' ${ }^{\prime}$-diphosphate inhibit ribonucleotide reductases. Proc. Natl. Acad. Sci. USA 2007, 104, 14324-14329. [CrossRef] [PubMed]

179. Aye, Y.; Brignole, E.J.; Long, M.J.; Chittuluru, J.; Drennan, C.L.; Asturias, F.J.; Stubbe, J. Clofarabine targets the large subunit (alpha) of human ribonucleotide reductase in live cells by assembly into persistent hexamers. Chem. Biol. 2012, 19, 799-805. [CrossRef] [PubMed]

180. Aye, Y.; Stubbe, J. Clofarabine $5^{\prime}$-di and -triphosphates inhibit human ribonucleotide reductase by altering the quaternary structure of its large subunit. Proc. Natl. Acad. Sci. USA 2011, 108, 9815-9820. [CrossRef] [PubMed]

181. Wisitpitthaya, S.; Zhao, Y.; Long, M.J.; Li, M.; Fletcher, E.A.; Blessing, W.A.; Weiss, R.S.; Aye, Y. Cladribine and Fludarabine Nucleotides Induce Distinct Hexamers Defining a Common Mode of Reversible RNR Inhibition. ACS Chem. Biol. 2016, 11, 2021-2032. [CrossRef] [PubMed]

182. Tay, B.S.; Lilley, R.M.; Murray, A.W.; Atkinson, M.R. Inhibition of phosphoribosyl pyrophosphate amidotransferase from Ehrlich ascites-tumour cells by thiopurine nucleotides. Biochem. Pharmacol. 1969, 18, 936-938. [CrossRef]

183. Tidd, D.M.; Paterson, A.R. Distinction between inhibition of purine nucleotide synthesis and the delayed cytotoxic reaction of 6-mercaptopurine. Cancer Res. 1974, 34, 733-737. [PubMed]

184. Longley, D.B.; Harkin, D.P.; Johnston, P.G. 5-fluorouracil: Mechanisms of action and clinical strategies. Nat. Rev. Cancer 2003, 3, 330-338. [CrossRef] [PubMed]

185. Wilson, P.M.; Danenberg, P.V.; Johnston, P.G.; Lenz, H.J.; Ladner, R.D. Standing the test of time: Targeting thymidylate biosynthesis in cancer therapy. Nat. Rev. Clin. Oncol. 2014, 11, 282-298. [CrossRef] [PubMed]

186. Costi, M.P.; Ferrari, S.; Venturelli, A.; Calo, S.; Tondi, D.; Barlocco, D. Thymidylate synthase structure, function and implication in drug discovery. Curr. Med. Chem. 2005, 12, 2241-2258. [CrossRef] [PubMed]

187. Santi, D.V.; McHenry, C.S.; Sommer, H. Mechanism of interaction of thymidylate synthetase with 5-fluorodeoxyuridylate. Biochemistry 1974, 13, 471-481. [CrossRef] [PubMed]

188. Sommer, H.; Santi, D.V. Purification and amino acid analysis of an active site peptide from thymidylate synthetase containing covalently bound 5-fluoro-2'-deoxyuridylate and methylenetetrahydrofolate. Biochem. Biophys. Res. Commun. 1974, 57, 689-695. [CrossRef]

189. Morgan, R.G. Leucovorin enhancement of the effects of the fluoropyrimidines on thymidylate synthase. Cancer 1989, 63, 1008-1012. [CrossRef]

190. Temmink, O.H.; Comijn, E.M.; Fukushima, M.; Peters, G.J. Intracellular thymidylate synthase inhibition by trifluorothymidine in FM3A cells. Nucleosides Nucleotides Nucleic Acids 2004, 23, 1491-1494. [CrossRef] [PubMed]

191. Cohen, S.S. On the nature of thymineless death. Ann. N. Y. Acad. Sci. 1971, 186, 292-301. [CrossRef] [PubMed]

192. Goulian, M.; Bleile, B.M.; Dickey, L.M.; Grafstrom, R.H.; Ingraham, H.A.; Neynaber, S.A.; Peterson, M.S.; Tseng, B.Y. Mechanism of thymineless death. Adv. Exp. Med. Biol. 1986, 195, 89-95. [PubMed]

193. Houghton, J.A.; Tillman, D.M.; Harwood, F.G. Ratio of $2^{\prime}$-deoxyadenosine- $5^{\prime}$ -triphosphate/thymidine-5'-triphosphate influences the commitment of human colon carcinoma cells to thymineless death. Clin. Cancer Res. 1995, 1, 723-730. [PubMed]

194. Caradonna, S.J.; Cheng, Y.C. The role of deoxyuridine triphosphate nucleotidohydrolase, uracil-DNA glycosylase, and DNA polymerase alpha in the metabolism of FUdR in human tumor cells. Mol. Pharmacol. 1980, 18, 513-520. [PubMed] 
195. Suzuki, N.; Emura, T.; Fukushima, M. Mode of action of trifluorothymidine (TFT) against DNA replication and repair enzymes. Int. J. Oncol. 2011, 39, 263-270. [CrossRef] [PubMed]

196. Tanaka, M.; Yoshida, S.; Saneyoshi, M.; Yamaguchi, T. Utilization of 5-fluoro-2'-deoxyuridine triphosphate and 5-fluoro-2'-deoxycytidine triphosphate in DNA synthesis by DNA polymerases alpha and beta from calf thymus. Cancer Res. 1981, 41, 4132-4135. [PubMed]

197. Yoshida, S.; Masaki, S. Utilization in vitro of deoxyuridine triphosphate in DNA synthesis by DNA polymerases alpha and beta from calf thymus. Biochim. Biophys. Acta 1979, 561, 396-402. [CrossRef]

198. Hagen, L.; Pena-Diaz, J.; Kavli, B.; Otterlei, M.; Slupphaug, G.; Krokan, H.E. Genomic uracil and human disease. Exp. Cell. Res. 2006, 312, 2666-2672. [CrossRef] [PubMed]

199. Wyatt, M.D.; Wilson, D.M., 3rd. Participation of DNA repair in the response to 5-fluorouracil. Cell. Mol. Life Sci. 2009, 66, 788-799. [CrossRef] [PubMed]

200. Fischer, F.; Baerenfaller, K.; Jiricny, J. 5-Fluorouracil is efficiently removed from DNA by the base excision and mismatch repair systems. Gastroenterology 2007, 133, 1858-1868. [CrossRef] [PubMed]

201. Suzuki, S.; Iwaizumi, M.; Yamada, H.; Sugiyama, T.; Hamaya, Y.; Furuta, T.; Kanaoka, S.; Sugimura, H.; Miyajima, H.; Osawa, S.; et al. MBD4 frameshift mutation caused by DNA mismatch repair deficiency enhances cytotoxicity by trifluridine, an active antitumor agent of TAS-102, in colorectal cancer cells. Oncotarget 2018, 9, 11477-11488. [CrossRef] [PubMed]

202. Sjolund, A.B.; Senejani, A.G.; Sweasy, J.B. MBD4 and TDG: Multifaceted DNA glycosylases with ever expanding biological roles. Mutat. Res. 2013, 743-744, 12-25. [CrossRef] [PubMed]

203. Krokan, H.E.; Drablos, F.; Slupphaug, G. Uracil in DNA-Occurrence, consequences and repair. Oncogene 2002, 21, 8935-8948. [CrossRef] [PubMed]

204. Doong, S.L.; Dolnick, B.J. 5-Fluorouracil substitution alters pre-mRNA splicing in vitro. J. Biol. Chem. 1988, 263, 4467-4473. [PubMed]

205. Glazer, R.I.; Lloyd, L.S. Association of cell lethality with incorporation of 5-fluorouracil and 5-fluorouridine into nuclear RNA in human colon carcinoma cells in culture. Mol. Pharmacol. 1982, 21, 468-473. [PubMed]

206. Geoffroy, F.J.; Allegra, C.J.; Sinha, B.; Grem, J.L. Enhanced cytotoxicity with interleukin-1 alpha and 5-fluorouracil in HCT116 colon cancer cells. Oncol. Res. 1994, 6, 581-591. [PubMed]

207. Pettersen, H.S.; Visnes, T.; Vagbo, C.B.; Svaasand, E.K.; Doseth, B.; Slupphaug, G.; Kavli, B.; Krokan, H.E. UNG-initiated base excision repair is the major repair route for 5-fluorouracil in DNA, but 5-fluorouracil cytotoxicity depends mainly on RNA incorporation. Nucleic Acids Res. 2011, 39, 8430-8444. [CrossRef] [PubMed]

208. Ison, G.; Beaver, J.A.; McGuinn, W.D., Jr.; Palmby, T.R.; Dinin, J.; Charlab, R.; Marathe, A.; Jin, R.; Liu, Q.; Chen, X.H.; et al. FDA Approval: Uridine Triacetate for the Treatment of Patients Following Fluorouracil or Capecitabine Overdose or Exhibiting Early-Onset Severe Toxicities Following Administration of These Drugs. Clin. Cancer Res. 2016, 22, 4545-4549. [CrossRef] [PubMed]

209. Jensen, K.; Johnson, L.A.; Jacobson, P.A.; Kachler, S.; Kirstein, M.N.; Lamba, J.; Klotz, K.N. Cytotoxic purine nucleoside analogues bind to A1, A2A, and A3 adenosine receptors. Naunyn-Schmiedeberg's Arch. Pharmacol. 2012, 385, 519-525. [CrossRef] [PubMed]

210. Komi, Y.; Ohno, O.; Suzuki, Y.; Shimamura, M.; Shimokado, K.; Umezawa, K.; Kojima, S. Inhibition of tumor angiogenesis by targeting endothelial surface ATP synthase with sangivamycin. Jpn. J. Clin. Oncol. 2007, 37, 867-873. [CrossRef] [PubMed]

211. Priebe, T.; Kandil, O.; Nakic, M.; Pan, B.F.; Nelson, J.A. Selective modulation of antibody response and natural killer cell activity by purine nucleoside analogues. Cancer Res. 1988, 48, 4799-4803. [PubMed]

212. Priebe, T.; Platsoucas, C.D.; Nelson, J.A. Adenosine receptors and modulation of natural killer cell activity by purine nucleosides. Cancer Res. 1990, 50, 4328-4331. [PubMed]

213. Maaser, K.; Hopfner, M.; Kap, H.; Sutter, A.P.; Barthel, B.; von Lampe, B.; Zeitz, M.; Scherubl, H. Extracellular nucleotides inhibit growth of human oesophageal cancer cells via P2Y(2)-receptors. Br. J. Cancer 2002, 86, 636-644. [CrossRef] [PubMed]

214. De Clercq, E.; Balzarini, J.; Madej, D.; Hansske, F.; Robins, M.J. Nucleic acid related compounds. 51. Synthesis and biological properties of sugar-modified analogues of the nucleoside antibiotics tubercidin, toyocamycin, sangivamycin, and formycin. J. Med. Chem. 1987, 30, 481-486. [CrossRef] [PubMed] 
215. Ri, M.; Tashiro, E.; Oikawa, D.; Shinjo, S.; Tokuda, M.; Yokouchi, Y.; Narita, T.; Masaki, A.; Ito, A.; Ding, J.; et al. Identification of Toyocamycin, an agent cytotoxic for multiple myeloma cells, as a potent inhibitor of ER stress-induced XBP1 mRNA splicing. Blood Cancer J. 2012, 2, e79. [CrossRef] [PubMed]

216. Cohen, M.B.; Glazer, R.I. Cytotoxicity and the inhibition of ribosomal RNA processing in human colon carcinoma cells. Mol. Pharmacol. 1985, 27, 308-313. [PubMed]

217. Finch, R.A.; Revankar, G.R.; Chan, P.K. Structural and functional relationships of toyocamycin on NPM-translocation. Anti-Cancer Drug Des. 1997, 12, 205-215.

218. Mooberry, S.L.; Stratman, K.; Moore, R.E. Tubercidin stabilizes microtubules against vinblastine-induced depolymerization, a taxol-like effect. Cancer Lett. 1995, 96, 261-266. [CrossRef]

219. Awrich, A.; Fletcher, W.S.; Klotz, J.H.; Minton, J.P.; Hill, G.J., 2nd; Aust, J.B.; Grage, T.B.; Multhauf, P.M. 5 -FU versus combination therapy with tubercidin, streptozotocin, and 5-FU in the treatment of pancreatic carcinomas: COG protocol 7230. J. Surg. Oncol. 1979, 12, 267-273. [CrossRef] [PubMed]

220. Cavins, J.A.; Hall, T.C.; Olson, K.B.; Khung, C.L.; Horton, J.; Colsky, J.; Shadduck, R.K. Initial toxicity study of sangivamycin (NSC-65346). Cancer Chemother. Rep. 1967, 51, 197-200. [PubMed]

221. Wilson, W.L. Phase I study with toyocamycin (NSC-63701). Cancer Chemother. Rep. 1968, 52, $301-303$. [PubMed]

222. Loomis, C.R.; Bell, R.M. Sangivamycin, a nucleoside analogue, is a potent inhibitor of protein kinase C. J. Biol. Chem. 1988, 263, 1682-1692. [PubMed]

223. Burgess, G.H.; Bloch, A.; Stoll, H.; Milgrom, H.; Helm, F.; Klein, E. Effect of topical tubercidin on basal cell carcinomas and actinic keratoses. Cancer 1974, 34, 250-253. [CrossRef]

224. Kraybill, W.G., Jr.; Anderson, D.D.; Lindell, T.D.; Fletcher, W.S. Islet cell carcinoma of the pancreas: Effective therapy with 5-fluorouracil, streptozotocin, and tubercidin. Am. Surg. 1976, 42, 467-470. [PubMed]

225. Gupta, R.S.; Mehta, K.D. Genetic and biochemical studies on mutants of CHO cells resistant to 7-deazapurine nucleosides: Differences in the mechanisms of action of toyocamycin and tubercidin. Biochem. Biophys. Res. Commun. 1984, 120, 88-95. [CrossRef]

226. Johnston, J.B. Mechanism of action of pentostatin and cladribine in hairy cell leukemia. Leuk. Lymphoma 2011, 52 (Suppl. S2), 43-45. [CrossRef] [PubMed]

227. Bosanquet, A.G.; Richards, S.M.; Wade, R.; Else, M.; Matutes, E.; Dyer, M.J.; Rassam, S.M.; Durant, J.; Scadding, S.M.; Raper, S.L.; et al. Drug cross-resistance and therapy-induced resistance in chronic lymphocytic leukaemia by an enhanced method of individualised tumour response testing. Br. J. Haematol. 2009, 146, 384-395. [CrossRef] [PubMed]

228. Homminga, I.; Zwaan, C.M.; Manz, C.Y.; Parker, C.; Bantia, S.; Smits, W.K.; Higginbotham, F.; Pieters, R.; Meijerink, J.P. In vitro efficacy of forodesine and nelarabine (ara-G) in pediatric leukemia. Blood 2011, 118, 2184-2190. [CrossRef] [PubMed]

229. Yamauchi, T.; Uzui, K.; Nishi, R.; Tasaki, T.; Ueda, T. A nelarabine-resistant T-lymphoblastic leukemia CCRF-CEM variant cell line is cross-resistant to the purine nucleoside phosphorylase inhibitor forodesine. Anticancer Res. 2014, 34, 4885-4892. [PubMed]

230. Balis, F.M.; Holcenberg, J.S.; Bleyer, W.A. Clinical pharmacokinetics of commonly used anticancer drugs. Clin. Pharmacokinet. 1983, 8, 202-232. [CrossRef] [PubMed]

231. Lennard, L. Therapeutic drug monitoring of antimetabolic cytotoxic drugs. Br. J. Clin. Pharmacol. 1999, 47, 131-143. [CrossRef] [PubMed]

232. Budman, D.R. Capecitabine. Investig. New Drugs 2000, 18, 355-363. [CrossRef]

233. Braess, J.; Freund, M.; Hanauske, A.; Heil, G.; Kaufmann, C.; Kern, W.; Schussler, M.; Hiddemann, W.; Schleyer, E. Oral cytarabine ocfosfate in acute myeloid leukemia and non-Hodgkin's lymphoma—Phase I/II studies and pharmacokinetics. Leukemia 1998, 12, 1618-1626. [CrossRef] [PubMed]

234. Koolen, S.L.; Witteveen, P.O.; Jansen, R.S.; Langenberg, M.H.; Kronemeijer, R.H.; Nol, A.; Garcia-Ribas, I.; Callies, S.; Benhadji, K.A.; Slapak, C.A.; et al. Phase I study of Oral gemcitabine prodrug (LY2334737) alone and in combination with erlotinib in patients with advanced solid tumors. Clin. Cancer Res. 2011, 17, 6071-6082. [CrossRef] [PubMed]

235. Liu, X.; Kantarjian, H.; Plunkett, W. Sapacitabine for cancer. Expert Opin. Investig. Drugs 2012, 21, 541-555. [CrossRef] [PubMed] 
236. Gandhi, V.; Plunkett, W.; Rodriguez, C.O., Jr.; Nowak, B.J.; Du, M.; Ayres, M.; Kisor, D.F.; Mitchell, B.S.; Kurtzberg, J.; Keating, M.J. Compound GW506U78 in refractory hematologic malignancies: Relationship between cellular pharmacokinetics and clinical response. J. Clin. Oncol. 1998, 16, 3607-3615. [CrossRef] [PubMed]

237. Chun, H.G.; Leyland-Jones, B.; Cheson, B.D. Fludarabine phosphate: A synthetic purine antimetabolite with significant activity against lymphoid malignancies. J. Clin. Oncol. 1991, 9, 175-188. [CrossRef] [PubMed]

238. Kawashima, K.; Nagura, E.; Yamada, K.; Hamajima, N. Leukemia relapse in long-term survivors of acute leukemia. Cancer 1985, 56, 88-94. [CrossRef]

239. Riccardi, R.; Vigersky, R.A.; Barnes, S.; Bleyer, W.A.; Poplack, D.G. Methotrexate levels in the interstitial space and seminiferous tubule of rat testis. Cancer Res. 1982, 42, 1617-1619. [PubMed]

240. Kalaria, R.N.; Harik, S.I. Nucleoside transporter of cerebral microvessels and choroid plexus. J. Neurochem. 1986, 47, 1849-1856. [CrossRef] [PubMed]

241. Varatharajan, L.; Thomas, S.A. The transport of anti-HIV drugs across blood-CNS interfaces: Summary of current knowledge and recommendations for further research. Antivir. Res. 2009, 82, A99-A109. [CrossRef] [PubMed]

242. Tamai, I.; Tsuji, A. Transporter-mediated permeation of drugs across the blood-brain barrier. J. Pharm. Sci. 2000, 89, 1371-1388. [CrossRef]

243. Saidijam, M.; Karimi Dermani, F.; Sohrabi, S.; Patching, S.G. Efflux proteins at the blood-brain barrier: Review and bioinformatics analysis. Xenobiotica 2018, 48, 506-532. [CrossRef] [PubMed]

244. Lindemalm, S.; Liliemark, J.; Larsson, B.S.; Albertioni, F. Distribution of 2-chloro-2'-deoxyadenosine, 2-chloro-2'-arabino-fluoro-2'-deoxyadenosine, fludarabine and cytarabine in mice: A whole-body autoradiography study. Med. Oncol. 1999, 16, 239-244. [CrossRef] [PubMed]

245. Pardridge, W.M.; Yoshikawa, T.; Kang, Y.S.; Miller, L.P. Blood-brain barrier transport and brain metabolism of adenosine and adenosine analogs. J. Pharmacol. Exp. Ther. 1994, 268, 14-18. [PubMed]

246. Phoenix, T.N.; Patmore, D.M.; Boop, S.; Boulos, N.; Jacus, M.O.; Patel, Y.T.; Roussel, M.F.; Finkelstein, D.; Goumnerova, L.; Perreault, S.; et al. Medulloblastoma Genotype Dictates Blood Brain Barrier Phenotype. Cancer Cell 2016, 29, 508-522. [CrossRef] [PubMed]

247. Hustu, H.O.; Aur, R.J.; Verzosa, M.S.; Simone, J.V.; Pinkel, D. Prevention of central nervous system leukemia by irradiation. Cancer 1973, 32, 585-597. [CrossRef]

248. Wahidijat, I.; Markum, A.H.; Abdulsalam, M.; Muslichan, S.; Odang, O. Prophylactic treatment of meningeal leukemia in children by intrathecal methotrexate. Acta Haematol. 1972, 47, 81-88. [CrossRef] [PubMed]

249. Wang, J.J.; Pratt, C.B. Intrathecal arabinosyl cytosine in meningeal leukemia. Cancer 1970, 25, 531-534. [CrossRef]

250. Abromowitch, M.; Ochs, J.; Pui, C.H.; Kalwinsky, D.; Rivera, G.K.; Fairclough, D.; Look, A.T.; Hustu, H.O.; Murphy, S.B.; Evans, W.E.; et al. High-dose methotrexate improves clinical outcome in children with acute lymphoblastic leukemia: St. Jude Total Therapy Study X. Med. Pediatr. Oncol. 1988, 16, 297-303. [CrossRef] [PubMed]

251. Morra, E.; Lazzarino, M.; Inverardi, D.; Brusamolino, E.; Orlandi, E.; Canevari, A.; Pagnucco, G.; Bernasconi, C. Systemic high-dose ara-C for the treatment of meningeal leukemia in adult acute lymphoblastic leukemia and non-Hodgkin's lymphoma. J. Clin. Oncol. 1986, 4, 1207-1211. [CrossRef] [PubMed]

252. Felix, A.; Leblanc, T.; Petit, A.; Nelkem, B.; Bertrand, Y.; Gandemer, V.; Sirvent, A.; Paillard, C.; Schmitt, C.; Rohrlich, P.S.; et al. Acute Myeloid Leukemia With Central Nervous System Involvement in Children: Experience From the French Protocol Analysis ELAM02. J. Pediatr. Hematol. Oncol. 2018, 40, 43-47. [CrossRef] [PubMed]

253. Ho, D.H.; Frei, E., 3rd. Clinical pharmacology of 1-beta-d-arabinofuranosyl cytosine. Clin. Pharmacol. Ther. 1971, 12, 944-954. [CrossRef] [PubMed]

254. Robak, P.; Robak, T. Older and new purine nucleoside analogs for patients with acute leukemias. Cancer Treat. Rev. 2013, 39, 851-861. [CrossRef] [PubMed]

255. Bouffard, D.Y.; Laliberte, J.; Momparler, R.L. Kinetic studies on 2' '2' -difluorodeoxycytidine (Gemcitabine) with purified human deoxycytidine kinase and cytidine deaminase. Biochem. Pharmacol. 1993, 45, 1857-1861. [CrossRef] 
256. Mahfouz, R.Z.; Jankowska, A.; Ebrahem, Q.; Gu, X.; Visconte, V.; Tabarroki, A.; Terse, P.; Covey, J.; Chan, K.; Ling, Y.; et al. Increased CDA expression/activity in males contributes to decreased cytidine analog half-life and likely contributes to worse outcomes with 5-azacytidine or decitabine therapy. Clin. Cancer Res. 2013, 19, 938-948. [CrossRef] [PubMed]

257. Serdjebi, C.; Seitz, J.F.; Ciccolini, J.; Duluc, M.; Norguet, E.; Fina, F.; Lacarelle, B.; Ouafik, L.; Dahan, L. Rapid deaminator status is associated with poor clinical outcome in pancreatic cancer patients treated with a gemcitabine-based regimen. Pharmacogenomics 2013, 14, 1047-1051. [CrossRef] [PubMed]

258. Abraham, A.; Varatharajan, S.; Abbas, S.; Zhang, W.; Shaji, R.V.; Ahmed, R.; Abraham, A.; George, B.; Srivastava, A.; Chandy, M.; et al. Cytidine deaminase genetic variants influence RNA expression and cytarabine cytotoxicity in acute myeloid leukemia. Pharmacogenomics 2012, 13, 269-282. [CrossRef] [PubMed]

259. Serdjebi, C.; Ciccolini, J.; Fina, F.; Delarue, A.; Verschuur, A.; Lacarelle, B.; Ouafik, L.; Andre, N. Recipient/donor contradictory genotypes with impact on drug pharmacogenetics after liver transplant: A deadly gift? Pharmacogenet. Genom. 2014, 24, 527-529. [CrossRef] [PubMed]

260. Fanciullino, R.; Farnault, L.; Donnette, M.; Imbs, D.C.; Roche, C.; Venton, G.; Berda-Haddad, Y.; Ivanov, V.; Ciccolini, J.; Ouafik, L.; et al. CDA as a predictive marker for life-threatening toxicities in patients with AML treated with cytarabine. Blood Adv. 2018, 2, 462-469. [CrossRef] [PubMed]

261. Plunkett, W.; Liliemark, J.O.; Adams, T.M.; Nowak, B.; Estey, E.; Kantarjian, H.; Keating, M.J. Saturation of 1-beta-D-arabinofuranosylcytosine 5'-triphosphate accumulation in leukemia cells during high-dose 1-beta-D-arabinofuranosylcytosine therapy. Cancer Res. 1987, 47, 3005-3011. [PubMed]

262. Veltkamp, S.A.; Beijnen, J.H.; Schellens, J.H. Prolonged versus standard gemcitabine infusion: Translation of molecular pharmacology to new treatment strategy. Oncologist 2008, 13, 261-276. [CrossRef] [PubMed]

263. Hansen, R.M.; Quebbeman, E.; Anderson, T. 5-Fluorouracil by protracted venous infusion. A review of current progress. Oncology 1989, 46, 245-250. [CrossRef] [PubMed]

264. Zimm, S.; Collins, J.M.; Miser, J.; Chatterji, D.; Poplack, D.G. Cytosine arabinoside cerebrospinal fluid kinetics. Clin. Pharmacol. Ther. 1984, 35, 826-830. [CrossRef] [PubMed]

265. Bomgaars, L.; Geyer, J.R.; Franklin, J.; Dahl, G.; Park, J.; Winick, N.J.; Klenke, R.; Berg, S.L.; Blaney, S.M. Phase I trial of intrathecal liposomal cytarabine in children with neoplastic meningitis. J. Clin. Oncol. 2004, 22, 3916-3921. [CrossRef] [PubMed]

266. Kim, S.; Chatelut, E.; Kim, J.C.; Howell, S.B.; Cates, C.; Kormanik, P.A.; Chamberlain, M.C. Extended CSF cytarabine exposure following intrathecal administration of DTC 101. J. Clin. Oncol. 1993, 11, 2186-2193. [CrossRef] [PubMed]

267. Ploylearmsaeng, S.A.; Fuhr, U.; Jetter, A. How may anticancer chemotherapy with fluorouracil be individualised? Clin. Pharmacokinet. 2006, 45, 567-592. [CrossRef] [PubMed]

268. Capitain, O.; Boisdron-Celle, M.; Poirier, A.L.; Abadie-Lacourtoisie, S.; Morel, A.; Gamelin, E. The influence of fluorouracil outcome parameters on tolerance and efficacy in patients with advanced colorectal cancer. Pharmacogenom. J. 2008, 8, 256-267. [CrossRef] [PubMed]

269. Deenen, M.J.; Tol, J.; Burylo, A.M.; Doodeman, V.D.; de Boer, A.; Vincent, A.; Guchelaar, H.J.; Smits, P.H.; Beijnen, J.H.; Punt, C.J.; et al. Relationship between single nucleotide polymorphisms and haplotypes in DPYD and toxicity and efficacy of capecitabine in advanced colorectal cancer. Clin. Cancer Res. 2011, 17, 3455-3468. [CrossRef] [PubMed]

270. Buchel, B.; Rhyn, P.; Schurch, S.; Buhr, C.; Amstutz, U.; Largiader, C.R. LC-MS/MS method for simultaneous analysis of uracil, 5,6-dihydrouracil, 5-fluorouracil and 5-fluoro-5,6-dihydrouracil in human plasma for therapeutic drug monitoring and toxicity prediction in cancer patients. Biomed. Chromatogr. BMC 2013, 27, 7-16. [CrossRef] [PubMed]

271. Krynetski, E.Y.; Krynetskaia, N.F.; Yanishevski, Y.; Evans, W.E. Methylation of mercaptopurine, thioguanine, and their nucleotide metabolites by heterologously expressed human thiopurine S-methyltransferase. Mol. Pharmacol. 1995, 47, 1141-1147. [PubMed]

272. Rieger, H.; Schmidt, P.; Schaeffeler, E.; Abe, M.; Schiffhauer, M.; Schwab, M.; von Ahsen, N.; Zurek, G.; Kirchherr, H.; Shipkova, M.; et al. Validation of a high-performance liquid chromatography method for thiopurine S-methyltransferase activity in whole blood using 6-mercaptopurine as substrate. Clin. Chem. Lab. Med. 2018, 56, 803-809. [CrossRef] [PubMed] 
273. Karim, H.; Appell, M.L.; Fotoohi, A. Comparison of three methods for measuring thiopurine methyltransferase activity in red blood cells and human leukemia cells. J. Chromatogr. 2013, 939, 80-85. [CrossRef] [PubMed]

274. McLeod, H.L.; Krynetski, E.Y.; Relling, M.V.; Evans, W.E. Genetic polymorphism of thiopurine methyltransferase and its clinical relevance for childhood acute lymphoblastic leukemia. Leukemia 2000, 14, 567-572. [CrossRef] [PubMed]

275. Schmiegelow, K.; Forestier, E.; Kristinsson, J.; Soderhall, S.; Vettenranta, K.; Weinshilboum, R.; Wesenberg, F. Thiopurine methyltransferase activity is related to the risk of relapse of childhood acute lymphoblastic leukemia: Results from the NOPHO ALL-92 study. Leukemia 2009, 23, 557-564. [CrossRef] [PubMed]

276. Nielsen, S.N.; Grell, K.; Nersting, J.; Abrahamsson, J.; Lund, B.; Kanerva, J.; Jonsson, O.G.; Vaitkeviciene, G.; Pruunsild, K.; Hjalgrim, L.L.; et al. DNA-thioguanine nucleotide concentration and relapse-free survival during maintenance therapy of childhood acute lymphoblastic leukaemia (NOPHO ALL2008): A prospective substudy of a phase 3 trial. Lancet Oncol. 2017, 18, 515-524. [CrossRef]

277. Young, J.D. The SLC28 (CNT) and SLC29 (ENT) nucleoside transporter families: A 30-year collaborative odyssey. Biochem. Soc. Trans. 2016, 44, 869-876. [CrossRef] [PubMed]

278. Young, J.D.; Yao, S.Y.; Baldwin, J.M.; Cass, C.E.; Baldwin, S.A. The human concentrative and equilibrative nucleoside transporter families, SLC28 and SLC29. Mol. Asp. Med. 2013, 34, 529-547. [CrossRef] [PubMed]

279. Ritzel, M.W.; Ng, A.M.; Yao, S.Y.; Graham, K.; Loewen, S.K.; Smith, K.M.; Ritzel, R.G.; Mowles, D.A.; Carpenter, P.; Chen, X.Z.; et al. Molecular identification and characterization of novel human and mouse concentrative Na+-nucleoside cotransporter proteins (hCNT3 and mCNT3) broadly selective for purine and pyrimidine nucleosides (system cib). J. Biol. Chem. 2001, 276, 2914-2927. [CrossRef] [PubMed]

280. Wang, J. The plasma membrane monoamine transporter (PMAT): Structure, function, and role in organic cation disposition. Clin. Pharmacol. Ther. 2016, 100, 489-499. [CrossRef] [PubMed]

281. Marechal, R.; Mackey, J.R.; Lai, R.; Demetter, P.; Peeters, M.; Polus, M.; Cass, C.E.; Young, J.; Salmon, I.; Deviere, J.; et al. Human equilibrative nucleoside transporter 1 and human concentrative nucleoside transporter 3 predict survival after adjuvant gemcitabine therapy in resected pancreatic adenocarcinoma. Clin. Cancer Res. 2009, 15, 2913-2919. [CrossRef] [PubMed]

282. Drenberg, C.D.; Gibson, A.A.; Pounds, S.B.; Shi, L.; Rhinehart, D.P.; Li, L.; Hu, S.; Du, G.; Nies, A.T.; Schwab, M.; et al. OCTN1 Is a High-Affinity Carrier of Nucleoside Analogues. Cancer Res. 2017, 77, 2102-2111. [CrossRef] [PubMed]

283. Lai, L.; Tan, T.M. Role of glutathione in the multidrug resistance protein 4 (MRP4/ABCC4)-mediated efflux of cAMP and resistance to purine analogues. Biochem. J. 2002, 361, 497-503. [CrossRef] [PubMed]

284. Guo, Y.; Kock, K.; Ritter, C.A.; Chen, Z.S.; Grube, M.; Jedlitschky, G.; Illmer, T.; Ayres, M.; Beck, J.F.; Siegmund, W.; et al. Expression of ABCC-type nucleotide exporters in blasts of adult acute myeloid leukemia: Relation to long-term survival. Clin. Cancer Res. 2009, 15, 1762-1769. [CrossRef] [PubMed]

285. Fukuda, Y.; Schuetz, J.D. ABC transporters and their role in nucleoside and nucleotide drug resistance. Biochem. Pharmacol. 2012, 83, 1073-1083. [CrossRef] [PubMed]

286. Schilsky, R.L. Biochemical and clinical pharmacology of 5-fluorouracil. Oncology 1998, 12, 13-18. [PubMed]

287. Kanzaki, A.; Takebayashi, Y.; Bando, H.; Eliason, J.F.; Watanabe Si, S.; Miyashita, H.; Fukumoto, M.; Toi, M.; Uchida, T. Expression of uridine and thymidine phosphorylase genes in human breast carcinoma. Int. J. Cancer 2002, 97, 631-635. [CrossRef] [PubMed]

288. Temmink, O.H.; de Bruin, M.; Laan, A.C.; Turksma, A.W.; Cricca, S.; Masterson, A.J.; Noordhuis, P.; Peters, G.J. The role of thymidine phosphorylase and uridine phosphorylase in (fluoro)pyrimidine metabolism in peripheral blood mononuclear cells. Int.J. Biochem. Cell Biol. 2006, 38, 1759-1765. [CrossRef] [PubMed]

289. Bronckaers, A.; Gago, F.; Balzarini, J.; Liekens, S. The dual role of thymidine phosphorylase in cancer development and chemotherapy. Med. Res. Rev. 2009, 29, 903-953. [CrossRef] [PubMed]

290. Hozumi, Y.; Tanaka, T.; Nakano, T.; Matsui, H.; Nasu, T.; Koike, S.; Kakehata, S.; Ito, T.; Goto, K. Orotate phosphoribosyltransferase localizes to the Golgi complex and its expression levels affect the sensitivity to anti-cancer drug 5-fluorouracil. Biomed. Res. 2015, 36, 403-409. [CrossRef] [PubMed]

291. Yasumatsu, R.; Nakashima, T.; Komune, S. Overexpression of the orotate phosphoribosyl-transferase gene enhances the effect of 5-Fluorouracil in head and neck squamous cell carcinoma in vitro. J. Oncol. 2012, 2012, 649605. [CrossRef] [PubMed] 
292. Ochiai, T.; Umeki, M.; Miyake, H.; Iida, T.; Okumura, M.; Ohno, K.; Sakamoto, M.; Miyoshi, N.; Takahashi, M.; Tsumura, H.; et al. Impact of 5-fluorouracil metabolizing enzymes on chemotherapy in patients with resectable colorectal cancer. Oncol. Rep. 2014, 32, 887-892. [CrossRef] [PubMed]

293. Komori, S.; Osada, S.; Tomita, H.; Nishio, K.; Kumazawa, I.; Tachibana, S.; Tsuchiya, J.; Yoshida, K. Predictive value of orotate phosphoribosyltransferase in colorectal cancer patients receiving 5-FU-based chemotherapy. Mol. Clin. Oncol. 2013, 1, 453-460. [CrossRef] [PubMed]

294. Kajiwara, T.; Nishina, T.; Hyodo, I.; Moriwaki, T.; Endo, S.; Nasu, J.; Hori, S.; Matsuura, B.; Hiasa, Y.; Onji, M. High orotate phosphoribosyltransferase gene expression predicts complete response to chemoradiotherapy in patients with squamous cell carcinoma of the esophagus. Oncology 2009, 76, 342-349. [CrossRef] [PubMed]

295. Ichikawa, W.; Takahashi, T.; Suto, K.; Sasaki, Y.; Hirayama, R. Orotate phosphoribosyltransferase gene polymorphism predicts toxicity in patients treated with bolus 5-fluorouracil regimen. Clin. Cancer Res. 2006, 12, 3928-3934. [CrossRef] [PubMed]

296. Elgemeie, G.H. Thioguanine, mercaptopurine: Their analogs and nucleosides as antimetabolites. Curr. Pharm. Des. 2003, 9, 2627-2642. [CrossRef] [PubMed]

297. Monnat, R.J., Jr. Molecular analysis of spontaneous hypoxanthine phosphoribosyltransferase mutations in thioguanine-resistant HL-60 human leukemia cells. Cancer Res. 1989, 49, 81-87. [PubMed]

298. Verhoef, V.; Sarup, J.; Fridland, A. Identification of the mechanism of activation of 9-beta-D-arabinofuranosyladenine in human lymphoid cells using mutants deficient in nucleoside kinases. Cancer Res. 1981, 41, 4478-4483. [PubMed]

299. Hurley, M.C.; Lin, B.; Fox, I.H. Regulation of deoxyadenosine and nucleoside analog phosphorylation by human placental adenosine kinase. J. Biol. Chem. 1985, 260, 15675-15681. [PubMed]

300. Kees, U.R.; Ford, J.; Dawson, V.M.; Piall, E.; Aherne, G.W. Development of resistance to 1-beta-D-arabinofuranosylcytosine after high-dose treatment in childhood lymphoblastic leukemia: Analysis of resistance mechanism in established cell lines. Cancer Res. 1989, 49, 3015-3019. [PubMed]

301. Colly, L.P.; Peters, W.G.; Richel, D.; Arentsen-Honders, M.W.; Starrenburg, C.W.; Willemze, R. Deoxycytidine kinase and deoxycytidine deaminase values correspond closely to clinical response to cytosine arabinoside remission induction therapy in patients with acute myelogenous leukemia. Semin. Oncol. 1987, 14, 257-261. [PubMed]

302. Genini, D.; Adachi, S.; Chao, Q.; Rose, D.W.; Carrera, C.J.; Cottam, H.B.; Carson, D.A.; Leoni, L.M. Deoxyadenosine analogs induce programmed cell death in chronic lymphocytic leukemia cells by damaging the DNA and by directly affecting the mitochondria. Blood 2000, 96, 3537-3543. [PubMed]

303. Sakamoto, K.; Yokogawa, T.; Ueno, H.; Oguchi, K.; Kazuno, H.; Ishida, K.; Tanaka, N.; Osada, A.; Yamada, Y.; Okabe, H.; et al. Crucial roles of thymidine kinase 1 and deoxyUTPase in incorporating the antineoplastic nucleosides trifluridine and 2'-deoxy-5-fluorouridine into DNA. Int. J. Oncol. 2015, 46, 2327-2334. [CrossRef] [PubMed]

304. Wang, L.; Munch-Petersen, B.; Herrstrom Sjoberg, A.; Hellman, U.; Bergman, T.; Jornvall, H.; Eriksson, S. Human thymidine kinase 2: Molecular cloning and characterisation of the enzyme activity with antiviral and cytostatic nucleoside substrates. FEBS Lett. 1999, 443, 170-174. [CrossRef]

305. Priego, E.M.; Karlsson, A.; Gago, F.; Camarasa, M.J.; Balzarini, J.; Perez-Perez, M.J. Recent advances in thymidine kinase 2 (TK2) inhibitors and new perspectives for potential applications. Curr. Pharm. Des. 2012, 18, 2981-2994. [CrossRef] [PubMed]

306. Meier, C. cycloSal-pronucleotides design of chemical trojan horses. Mini Rev. Med. Chem. 2002, 2, $219-234$. [CrossRef] [PubMed]

307. Liou, J.Y.; Dutschman, G.E.; Lam, W.; Jiang, Z.; Cheng, Y.C. Characterization of human UMP/CMP kinase and its phosphorylation of D- and L-form deoxycytidine analogue monophosphates. Cancer Res. 2002, 62, 1624-1631. [PubMed]

308. Liou, J.Y.; Lai, H.R.; Hsu, C.H.; Chang, W.L.; Hsieh, M.J.; Huang, Y.C.; Cheng, Y.C. Modulation of human $\mathrm{UMP} / \mathrm{CMP}$ kinase affects activation and cellular sensitivity of deoxycytidine analogs. Biochem. Pharmacol. 2010, 79, 381-388. [CrossRef] [PubMed]

309. Yasuno, H.; Kurasawa, M.; Yanagisawa, M.; Sato, Y.; Harada, N.; Mori, K. Predictive markers of capecitabine sensitivity identified from the expression profile of pyrimidine nucleoside-metabolizing enzymes. Oncol. Rep. 2013, 29, 451-458. [CrossRef] [PubMed] 
310. Xu, Y.; Johansson, M.; Karlsson, A. Human UMP-CMP kinase 2, a novel nucleoside monophosphate kinase localized in mitochondria. J. Biol. Chem. 2008, 283, 1563-1571. [CrossRef] [PubMed]

311. Temmink, O.H.; Emura, T.; de Bruin, M.; Fukushima, M.; Peters, G.J. Therapeutic potential of the dual-targeted TAS-102 formulation in the treatment of gastrointestinal malignancies. Cancer Sci. 2007, 98, 779-789. [CrossRef] [PubMed]

312. Okabe-Kado, J.; Kasukabe, T.; Honma, Y. Differentiation inhibitory factor Nm23 as a prognostic factor for acute myeloid leukemia. Leuk. Lymphoma 1998, 32, 19-28. [CrossRef] [PubMed]

313. Yokoyama, A.; Okabe-Kado, J.; Wakimoto, N.; Kobayashi, H.; Sakashita, A.; Maseki, N.; Nakamaki, T.; Hino, K.; Tomoyasu, S.; Tsuruoka, N.; et al. Evaluation by multivariate analysis of the differentiation inhibitory factor nm23 as a prognostic factor in acute myelogenous leukemia and application to other hematologic malignancies. Blood 1998, 91, 1845-1851. [PubMed]

314. Bach, E.; Krahl, R.; Lange, T.; Schuler, F.; Al-Ali, H.; Buchner, T.; Haferlach, T.; Dolken, G.; Niederwieser, D.; Cross, M. Delayed processing of bone marrow samples reveals a prognostic pattern of NME mRNA expression in cytogenetically normal acute myeloid leukemia. Leuk. Lymphoma 2012, 53, 1561-1568. [CrossRef] [PubMed]

315. Steuart, C.D.; Burke, P.J. Cytidine deaminase and the development of resistance to arabinosyl cytosine. Nat. New Biol. 1971, 233, 109-110. [CrossRef] [PubMed]

316. Hubeek, I.; Stam, R.W.; Peters, G.J.; Broekhuizen, R.; Meijerink, J.P.; van Wering, E.R.; Gibson, B.E.; Creutzig, U.; Zwaan, C.M.; Cloos, J.; et al. The human equilibrative nucleoside transporter 1 mediates in vitro cytarabine sensitivity in childhood acute myeloid leukaemia. Br. J. Cancer 2005, 93, 1388-1394. [CrossRef] [PubMed]

317. Niitsu, N.; Ishii, Y.; Matsuda, A.; Honma, Y. Induction of differentiation of acute promyelocytic leukemia cells by a cytidine deaminase-resistant analogue of 1-beta-D-arabinofuranosylcytosine, 1-(2-deoxy-2-methylene-beta-D-erythro-pentofuranosyl)cytidine. Cancer Res. 2001, 61, 178-185. [PubMed]

318. Miwa, M.; Eda, H.; Ura, M.; Ouchi, K.F.; Keith, D.D.; Foley, L.H.; Ishitsuka, H. High susceptibility of human cancer xenografts with higher levels of cytidine deaminase to a $2^{\prime}$-deoxycytidine antimetabolite, 2'-deoxy-2'-methylidenecytidine. Clin. Cancer Res. 1998, 4, 493-497. [PubMed]

319. Chiba, P.; Tihan, T.; Szekeres, T.; Salamon, J.; Kraupp, M.; Eher, R.; Koller, U.; Knapp, W. Concordant changes of pyrimidine metabolism in blasts of two cases of acute myeloid leukemia after repeated treatment with ara-C in vivo. Leukemia 1990, 4, 761-765. [PubMed]

320. Gilbert, J.A.; Salavaggione, O.E.; Ji, Y.; Pelleymounter, L.L.; Eckloff, B.W.; Wieben, E.D.; Ames, M.M.; Weinshilboum, R.M. Gemcitabine pharmacogenomics: Cytidine deaminase and deoxycytidylate deaminase gene resequencing and functional genomics. Clin. Cancer Res. 2006, 12, 1794-1803. [CrossRef] [PubMed]

321. Elander, N.O.; Aughton, K.; Ghaneh, P.; Neoptolemos, J.P.; Palmer, D.H.; Cox, T.F.; Campbell, F.; Costello, E.; Halloran, C.M.; Mackey, J.R.; et al. Intratumoural expression of deoxycytidylate deaminase or ribonuceotide reductase subunit M1 expression are not related to survival in patients with resected pancreatic cancer given adjuvant chemotherapy. Br. J. Cancer 2018, 118, 1084-1088. [CrossRef] [PubMed]

322. Jansen, R.S.; Rosing, H.; Schellens, J.H.; Beijnen, J.H. Deoxyuridine analog nucleotides in deoxycytidine analog treatment: Secondary active metabolites? Fund. Clin. Pharmacol. 2011, 25, 172-185. [CrossRef] [PubMed]

323. Li, L.; Fridley, B.; Kalari, K.; Jenkins, G.; Batzler, A.; Safgren, S.; Hildebrandt, M.; Ames, M.; Schaid, D.; Wang, L. Gemcitabine and cytosine arabinoside cytotoxicity: Association with lymphoblastoid cell expression. Cancer Res. 2008, 68, 7050-7058. [CrossRef] [PubMed]

324. Rudd, S.G.; Valerie, N.C.K.; Helleday, T. Pathways controlling dNTP pools to maintain genome stability. DNA Repair 2016, 44, 193-204. [CrossRef] [PubMed]

325. Requena, C.E.; Perez-Moreno, G.; Horvath, A.; Vertessy, B.G.; Ruiz-Perez, L.M.; Gonzalez-Pacanowska, D.; Vidal, A.E. The nucleotidohydrolases DCTPP1 and dUTPase are involved in the cellular response to decitabine. Biochem. J. 2016, 473, 2635-2643. [CrossRef] [PubMed]

326. Almqvist, H.; Axelsson, H.; Jafari, R.; Dan, C.; Mateus, A.; Haraldsson, M.; Larsson, A.; Martinez Molina, D.; Artursson, P.; Lundback, T.; et al. CETSA screening identifies known and novel thymidylate synthase inhibitors and slow intracellular activation of 5-fluorouracil. Nat. Commun. 2016, 7, 11040. [CrossRef] [PubMed] 
327. Wilson, P.M.; Fazzone, W.; LaBonte, M.J.; Lenz, H.J.; Ladner, R.D. Regulation of human dUTPase gene expression and p53-mediated transcriptional repression in response to oxaliplatin-induced DNA damage. Nucleic Acids Res. 2009, 37, 78-95. [CrossRef] [PubMed]

328. Llona-Minguez, S.; Hoglund, A.; Jacques, S.A.; Johansson, L.; Calderon-Montano, J.M.; Claesson, M.; Loseva, O.; Valerie, N.C.K.; Lundback, T.; Piedrafita, J.; et al. Discovery of the First Potent and Selective Inhibitors of Human dCTP Pyrophosphatase 1. J. Med. Chem. 2016, 59, 1140-1148. [CrossRef] [PubMed]

329. Corson, T.W.; Cavga, H.; Aberle, N.; Crews, C.M. Triptolide directly inhibits dCTP pyrophosphatase. Chembiochem 2011, 12, 1767-1773. [CrossRef] [PubMed]

330. Kakuta, Y.; Naito, T.; Onodera, M.; Kuroha, M.; Kimura, T.; Shiga, H.; Endo, K.; Negoro, K.; Kinouchi, Y.; Shimosegawa, T. NUDT15 R139C causes thiopurine-induced early severe hair loss and leukopenia in Japanese patients with IBD. Pharmacogenom. J. 2016, 16, 280-285. [CrossRef] [PubMed]

331. Yang, J.J.; Landier, W.; Yang, W.; Liu, C.; Hageman, L.; Cheng, C.; Pei, D.; Chen, Y.; Crews, K.R.; Kornegay, N.; et al. Inherited NUDT15 variant is a genetic determinant of mercaptopurine intolerance in children with acute lymphoblastic leukemia. J. Clin. Oncol. 2015, 33, 1235-1242. [CrossRef] [PubMed]

332. Yang, S.K.; Hong, M.; Baek, J.; Choi, H.; Zhao, W.; Jung, Y.; Haritunians, T.; Ye, B.D.; Kim, K.J.; Park, S.H.; et al. A common missense variant in NUDT15 confers susceptibility to thiopurine-induced leukopenia. Nat. Genet. 2014, 46, 1017-1020. [CrossRef] [PubMed]

333. Moriyama, T.; Nishii, R.; Perez-Andreu, V.; Yang, W.; Klussmann, F.A.; Zhao, X.; Lin, T.N.; Hoshitsuki, K.; Nersting, J.; Kihira, K.; et al. NUDT15 polymorphisms alter thiopurine metabolism and hematopoietic toxicity. Nat. Genet. 2016, 48, 367-373. [CrossRef] [PubMed]

334. Valerie, N.C.; Hagenkort, A.; Page, B.D.; Masuyer, G.; Rehling, D.; Carter, M.; Bevc, L.; Herr, P.; Homan, E.; Sheppard, N.G.; et al. NUDT15 Hydrolyzes 6-Thio-DeoxyGTP to Mediate the Anticancer Efficacy of 6-Thioguanine. Cancer Res. 2016, 76, 5501-5511. [CrossRef] [PubMed]

335. Nishii, R.; Moriyama, T.; Janke, L.J.; Yang, W.; Suiter, C.C.; Lin, T.N.; Li, L.; Kihira, K.; Toyoda, H.; Hofmann, U.; et al. Preclinical evaluation of NUDT15-guided thiopurine therapy and its effects on toxicity and antileukemic efficacy. Blood 2018, 131, 2466-2474. [CrossRef] [PubMed]

336. Lin, S.; McLennan, A.G.; Ying, K.; Wang, Z.; Gu, S.; Jin, H.; Wu, C.; Liu, W.; Yuan, Y.; Tang, R.; et al. Cloning, expression, and characterization of a human inosine triphosphate pyrophosphatase encoded by the itpa gene. J. Biol. Chem. 2001, 276, 18695-18701. [CrossRef] [PubMed]

337. Menezes, M.R.; Waisertreiger, I.S.; Lopez-Bertoni, H.; Luo, X.; Pavlov, Y.I. Pivotal role of inosine triphosphate pyrophosphatase in maintaining genome stability and the prevention of apoptosis in human cells. PLoS ONE 2012, 7, e32313. [CrossRef] [PubMed]

338. Stocco, G.; Crews, K.R.; Evans, W.E. Genetic polymorphism of inosine-triphosphate-pyrophosphatase influences mercaptopurine metabolism and toxicity during treatment of acute lymphoblastic leukemia individualized for thiopurine-S-methyl-transferase status. Expert Opin. Drug Saf. 2010, 9, 23-37. [CrossRef] [PubMed]

339. Marinaki, A.M.; Duley, J.A.; Arenas, M.; Ansari, A.; Sumi, S.; Lewis, C.M.; Shobowale-Bakre, M.; Fairbanks, L.D.; Sanderson, J. Mutation in the ITPA gene predicts intolerance to azathioprine. Nucleosides Nucleotides Nucleic Acids 2004, 23, 1393-1397. [CrossRef] [PubMed]

340. Van Dieren, J.M.; Hansen, B.E.; Kuipers, E.J.; Nieuwenhuis, E.E.; Van der Woude, C.J. Meta-analysis: Inosine triphosphate pyrophosphatase polymorphisms and thiopurine toxicity in the treatment of inflammatory bowel disease. Aliment. Pharmacol. Ther. 2007, 26, 643-652. [CrossRef] [PubMed]

341. Schaller, T.; Herold, N. The Early Bird Catches the Worm-Can Evolution Teach us Lessons in Fighting HIV? Curr. HIV Res. 2016, 14, 183-210. [CrossRef] [PubMed]

342. Arnold, L.H.; Kunzelmann, S.; Webb, M.R.; Taylor, I.A. A continuous enzyme-coupled assay for triphosphohydrolase activity of HIV-1 restriction factor SAMHD1. Antimicrob. Agents Chemother. 2015, 59, 186-192. [CrossRef] [PubMed]

343. Herold, N.; Rudd, S.G.; Sanjiv, K.; Kutzner, J.; Bladh, J.; Paulin, C.B.J.; Helleday, T.; Henter, J.I.; Schaller, T. SAMHD1 protects cancer cells from various nucleoside-based antimetabolites. Cell Cycle 2017, 16, 1029-1038. [CrossRef] [PubMed]

344. Rudd, S.G.; Schaller, T.; Herold, N. SAMHD1 is a barrier to antimetabolite-based cancer therapies. Mol. Cell. Oncol. 2017, 4, e1287554. [CrossRef] [PubMed] 
345. Schneider, C.; Oellerich, T.; Baldauf, H.M.; Schwarz, S.M.; Thomas, D.; Flick, R.; Bohnenberger, H.; Kaderali, L.; Stegmann, L.; Cremer, A.; et al. SAMHD1 is a biomarker for cytarabine response and a therapeutic target in acute myeloid leukemia. Nat. Med. 2017, 23, 250. [CrossRef] [PubMed]

346. Herold, N.; Rudd, S.; Myrberg, I.H.; Sanjiv, K.; Ljungblad, L.; Kutzner, J.; Grander, D.; Kogner, P.; Rassidakis, G.; Helleday, T.; et al. Development of a Small Molecule Inhibitor for SAMHD1 to Improve Outcome for Patients with Acute Myelogenous Leukaemia and Relapsed T-Lymphoblastic Malignancies Treated with Nucleoside Analogues. Pediatr. Blood Cancer 2017, 64, S135.

347. Seamon, K.J.; Hansen, E.C.; Kadina, A.P.; Kashemirov, B.A.; McKenna, C.E.; Bumpus, N.N.; Stivers, J.T. Small molecule inhibition of SAMHD1 dNTPase by tetramer destabilization. J. Am. Chem. Soc. 2014, 136, 9822-9825. [CrossRef] [PubMed]

348. Seamon, K.J.; Stivers, J.T. A High-Throughput Enzyme-Coupled Assay for SAMHD1 dNTPase. J. Biomol. Screen 2015, 20, 801-809. [CrossRef] [PubMed]

349. Vena, F.; Li Causi, E.; Rodriguez-Justo, M.; Goodstal, S.; Hagemann, T.; Hartley, J.A.; Hochhauser, D. The MEK1/2 Inhibitor Pimasertib Enhances Gemcitabine Efficacy in Pancreatic Cancer Models by Altering Ribonucleotide Reductase Subunit-1 (RRM1). Clin. Cancer Res. 2015, 21, 5563-5577. [CrossRef] [PubMed]

350. Lee, J.H.; Park, J.H.; Jung, Y.; Kim, J.H.; Jong, H.S.; Kim, T.Y.; Bang, Y.J. Histone deacetylase inhibitor enhances 5-fluorouracil cytotoxicity by down-regulating thymidylate synthase in human cancer cells. Mol. Cancer Ther. 2006, 5, 3085-3095. [CrossRef] [PubMed]

351. Meyers, M.; Hwang, A.; Wagner, M.W.; Bruening, A.J.; Veigl, M.L.; Sedwick, W.D.; Boothman, D.A. A role for DNA mismatch repair in sensing and responding to fluoropyrimidine damage. Oncogene 2003, 22, 7376-7388. [CrossRef] [PubMed]

352. Triemer, T.; Messikommer, A.; Glasauer, S.M.K.; Alzeer, J.; Paulisch, M.H.; Luedtke, N.W. Superresolution imaging of individual replication forks reveals unexpected prodrug resistance mechanism. Proc. Natl. Acad. Sci. USA 2018, 115, E1366-E1373. [CrossRef] [PubMed]

353. Galmarini, C.M.; Clarke, M.L.; Falette, N.; Puisieux, A.; Mackey, J.R.; Dumontet, C. Expression of a non-functional p53 affects the sensitivity of cancer cells to gemcitabine. Int. J. Cancer 2002, 97, 439-445. [CrossRef] [PubMed]

354. Pettitt, A.R.; Sherrington, P.D.; Cawley, J.C. The effect of p53 dysfunction on purine analogue cytotoxicity in chronic lymphocytic leukaemia. Br. J. Haematol. 1999, 106, 1049-1051. [CrossRef] [PubMed]

355. Zoppoli, G.; Regairaz, M.; Leo, E.; Reinhold, W.C.; Varma, S.; Ballestrero, A.; Doroshow, J.H.; Pommier, Y. Putative DNA/RNA helicase Schlafen-11 (SLFN11) sensitizes cancer cells to DNA-damaging agents. Proc. Natl. Acad. Sci. USA 2012, 109, 15030-15035. [CrossRef] [PubMed]

356. Parrales, A.; Iwakuma, T. Targeting Oncogenic Mutant p53 for Cancer Therapy. Front. Oncol 2015, 5, 288. [CrossRef] [PubMed]

357. Zawacka-Pankau, J.; Selivanova, G. Pharmacological reactivation of p53 as a strategy to treat cancer. J. Intern. Med. 2015, 277, 248-259. [CrossRef] [PubMed]

358. Gardner, E.E.; Lok, B.H.; Schneeberger, V.E.; Desmeules, P.; Miles, L.A.; Arnold, P.K.; Ni, A.; Khodos, I.; de Stanchina, E.; Nguyen, T.; et al. Chemosensitive Relapse in Small Cell Lung Cancer Proceeds through an EZH2-SLFN11 Axis. Cancer Cell 2017, 31, 286-299. [CrossRef] [PubMed]

359. Tang, S.W.; Thomas, A.; Murai, J.; Trepel, J.B.; Bates, S.E.; Rajapakse, V.N.; Pommier, Y. Overcoming Resistance to DNA-Targeted Agents by Epigenetic Activation of Schlafen 11 (SLFN11) Expression with Class I Histone Deacetylase Inhibitors. Clin. Cancer Res. 2018, 24, 1944-1953. [CrossRef] [PubMed]

360. Tsukamoto, Y.; Kato, Y.; Ura, M.; Horii, I.; Ishitsuka, H.; Kusuhara, H.; Sugiyama, Y. A physiologically based pharmacokinetic analysis of capecitabine, a triple prodrug of 5-FU, in humans: The mechanism for tumor-selective accumulation of 5-FU. Pharm. Res. 2001, 18, 1190-1202. [CrossRef] [PubMed]

361. Ciccolini, J.; Serdjebi, C.; Le Thi Thu, H.; Lacarelle, B.; Milano, G.; Fanciullino, R. Nucleoside analogs: Ready to enter the era of precision medicine? Expert Opin. Drug Metab. Toxicol. 2016, 12, 865-877. [CrossRef] [PubMed]

(C) 2018 by the authors. Licensee MDPI, Basel, Switzerland. This article is an open access article distributed under the terms and conditions of the Creative Commons Attribution (CC BY) license (http:/ / creativecommons.org/licenses/by/4.0/). 